FABIANA CARSONI ALVES FERNANDES DA SILVA

A SOCIEDADE EM CONTA DE PARTICIPAÇÃO NO DIREITO TRIBUTÁRIO - IRPJ, CSL, CONTRIBUIÇÃO AO PIS E COFINS

Dissertação de Mestrado

Orientador: Prof. Dr. Roberto Quiroga Mosquera

UNIVERSIDADE DE SÃO PAULO

FACULDADE DE DIREITO

SÃO PAULO-SP

2020 



\title{
A SOCIEDADE EM CONTA DE PARTICIPAÇÃO NO DIREITO TRIBUTÁRIO - IRPJ, CSL, CONTRIBUIÇÃO AO PIS E COFINS
}

\begin{abstract}
Dissertação apresentada ao Programa de PósGraduação em Direito, da Faculdade de Direito da Universidade de São Paulo, como exigência parcial para a obtenção do título de Mestre em Direito, na área de concentração Direito Econômico, Financeiro e Direito Tributário, sob a orientação do Prof. Roberto Quiroga Mosquera.
\end{abstract}

UNIVERSIDADE DE SÃO PAULO

FACULDADE DE DIREITO

SÃO PAULO-SP 

Autorizo a reprodução e divulgação parcial deste trabalho, por qualquer meio convencional ou eletrônico, para fins de estudo e pesquisa, desde que citada a fonte.

\author{
Catalogação da Publicação
}

Serviço de Biblioteca e Documentação

Faculdade de Direito da Universidade de São Paulo

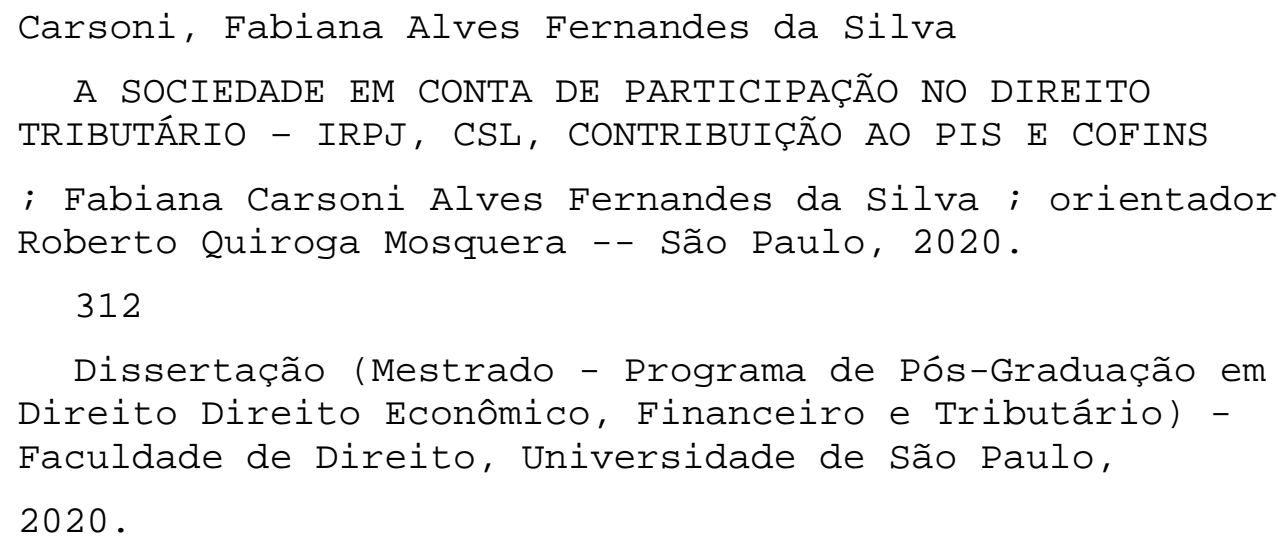

1. Sociedade em conta de participação. 2. Regime de Direito Privado - natureza, causa jurídica e características essenciais. 3. Relacionamento entre Direito Privado e Direito Tributário. 4. Regime tributário - IRPJ, CSL, contribuição ao PIS e COFINS. 5. Equiparação da sociedade em conta de participação à pessoa jurídica. I. Quiroga Mosquera, Roberto, orient. II. Título. 

Nome: Fabiana Carsoni Alves Fernandes da Silva

Título: A sociedade em conta de participação no direito tributário - IRPJ, CSL, contribuição ao PIS e COFINS.

Dissertação apresentada à Faculdade de Direito da Universidade de São Paulo para obtenção do título de Mestre em Direito Tributário.

Aprovada em:

Prof.

Julgamento:

Prof.

Julgamento:

Prof.

Julgamento:
Instituição:

Assinatura:

Instituição:

Assinatura:

Instituição:

Assinatura: 

Às minhas crianças, Cacau, Tito e Brotinho 



\section{AGRADECIMENTOS}

Agradeço à minha família. Aos meus pais, Rita de Cássia Carsoni Alves Fernandes da Silva e José Fernandes da Silva, pelo amor, carinho, suporte, educação e tudo o mais. Sem vocês, meus sonhos não teriam se concretizado. À minha irmã, Juliana Carsoni Fernandes da Silva, pelo exemplo de mulher determinada, competente e mãe trabalhadora. Agradeço ao meu companheiro e amigo, Marcos Engel Vieira Barbosa, pelo amor e por acreditar que tudo isso seria possível, dando-me apoio para que eu trilhasse esse caminho até o fim, mesmo após a chegada de nosso pequeno Tito.

Agradeço ao Professor Roberto Quiroga Mosquera, professor e advogado competente, sério e admirável, que aceitou o pedido para me guiar durante toda a execução deste trabalho, acreditou no tema por mim escolhido, deu-me liberdade para estruturar meu trabalho, confiando no resultado, e enriqueceu esta dissertação com suas ponderações e reflexões.

Agradeço aos Professores Luís Eduardo Schoueri, Humberto Ávila, Gerd Willi Rothmann (in memoriam) e Gustavo Gonçalves Vettori, pelas aulas ministradas na Faculdade de Direito da Universidade de São Paulo, aulas essas que contribuíram para meu crescimento e amadurecimento acadêmico e profissional. A excelência do ensino, a dedição, o rigor técnico e a seriedade dos Professores inspiram, motivam e engrandecem aqueles que têm o privilégio de estudar na Faculdade de Direito.

Agradeço aos Professores Roberto Quiroga Mosquera, Luís Eduardo Schoueri e Fábio Ulhoa Coelho, pelas valiosas contribuições formuladas na Banca de Qualificação deste trabalho, as quais permitiram o aprimoramento da minha dissertação.

Agradeço ao Ricardo Mariz de Oliveira, com quem tenho a honra e a satisfação de trabalhar e que me desafia diariamente, seja no escritório, seja no Instituto Brasileiro de Direito Tributário, sendo fonte de inspiração pela sabedoria, pela incansável busca pela excelência, pelo profissional competente e dedicado que é e pela generosidade. Devo ao Ricardo Mariz de Oliveira muitas das minhas conquistas profissionais.

Agradeço ao João Francisco Bianco, com quem tenho a honra e a satisfação de trabalhar, agregando à minha vida profissional com sua sabedoria, competência, experiência, leveza e amizade. Tive a sorte, a felicidade e o privilégio de contar com o apoio e os ensinamentos do João Francisco Bianco na orientação de trabalho entregue ao Insper, o qual, após maturação, deu origem ao meu livro Consórcios de empresas aspectos jurídicos relevantes, publicado em 2015. Depois, João Francisco Bianco seguiu 
me guiando e orientando, sendo entusiasta do meu ingresso no Mestrado, tendo, ainda, contribuído para esta dissertação com sua análise crítica e técnica.

Agradeço a todos aqueles que estiveram ao meu lado desde o início de minha carreira até os dias atuais, contribuindo para o meu desenvolvimento profissional, em especial a Elidie Palma Bifano, Bruno Fajersztajn, Ramon Tomazela Santos e Silvio José Gazzaneo Junior, que me inspiram, me apoiam, me ensinam e me desafiam.

Agradeço à minha equipe, que direta ou indiretamente viabilizou a elaboração e a conclusão deste trabalho e que me ensina e me instiga em nossos debates diários, em especial a Fernando Mariz Masagão, Paulo Coviello Filho, Nicolas Ciancio, Matheus Rocca, Márcio Pedrosa Jr., Mariana Alfonso, Gustavo Santin, Larissa Gimenez, Henrique Coutinho, Gabriel Campos, Marcelo Muratori, Gabriel Issa, Gabriel Laredo e Natália Molina.

Agradeço a Ana Carolina de Azeredo Souccar, Beatriz Faustino França, Bruna Simões, Carla Gomes Horner Hoe, Daniela Volpato, Francine Barreiros Rosalem, Helena Silveira, Juliana Natrielli, Marcelo Hasunuma, Marília Poletti, Patricia Bayer, Paula Kives Friedmann, Vanessa Sandrim, Vivian Brenner de Oliveira, Ricardo Campos Padovese e Paula Kumamoto, meus amigos de faculdade ou de escritório, pelo apoio, amizade e incentivo. Como sempre digo, eu me ufano de todos vocês.

Agradeço àqueles que conviveram comigo durante a pós-graduação e que se tornaram amigos e confidentes, em especial a Thais de Barros Meira, Emmanuel Abrantes, Leonardo Aguirra, Diego Aubin Miguita, Francisco Lisboa, Diogo Figueiredo, Andressa Pegoraro, Alexandre Evaristo Pinto e Caio Takano. 


\section{RESUMO}

SILVA, Fabiana Carsoni Alves Fernandes da. A sociedade em conta de participação no direito tributário - IRPJ, CSL, contribuição ao PIS e COFINS. 2020. 312 f. Dissertação (Mestrado em Direito Econômico, Financeiro e Tributário) - Faculdade de Direito, Universidade de São Paulo, São Paulo, 2020.

Nesta dissertação, analisa-se o regime tributário aplicável aos resultados e operações das sociedades em conta de participação em matéria de IRPJ, CSL, contribuição ao PIS e COFINS. Para tanto, examina-se a natureza, a causa jurídica e as características essenciais do referido instituto. Examina-se também o relacionamento entre Direito Privado e Direito Tributário, investigando-se se o último pode atribuir efeitos distintos aos institutos criados e regulados pelo primeiro. Após, historia-se o regime de tributação dos rendimentos, receitas e ganhos oriundos de negócios empreendidos por meio de sociedades em conta de participação, demonstrando-se que, com a edição do Decreto-lei n. 2303, de 21.11.1986 (art. $7^{\circ}$ ), a SCP foi equiparada à pessoa jurídica para efeito de apuração do imposto de renda, equiparação essa que é extensível à CSL e à contribuição ao PIS e à COFINS devidas no regime cumulativo. Em que pese haver debates em torno de sua validade, esclareceu-se nesta dissertação que a equiparação constitui critério de apuração do IRPJ, CSL e da contribuição ao PIS e da COFINS devidas no regime cumulativo, criado com vistas ao aprimoramento da fiscalização em torno do cumprimento da legislação tributária. Demonstrou-se que a equiparação atende aos art. 109 e 126 do CTN, além de não ferir, nem desfigurar, o regime jurídico de Direito Privado a que se submete a SCP, ficando preservadas sua natureza, sua causa jurídica e suas características essenciais. Explicou-se que, em decorrência desse critério de apuração do IRPJ, CSL e da contribuição ao PIS e da COFINS devidas no regime cumulativo, derivado da equiparação da SCP à pessoa jurídica, os resultados da sociedade devem ser tributados separadamente por um dos possíveis regimes de tributação da renda e da receita aplicáveis às pessoas jurídicas, não se misturando com os resultados do sócio ostensivo, obtidos fora do empreendimento da SCP.

Palavras-chave: Sociedade em conta de participação. Regime de Direito Privado natureza, causa jurídica e características essenciais. Relacionamento entre Direito Privado e Direito Tributário. Regime tributário - IRPJ, CSL, contribuição ao PIS e COFINS. Equiparação da sociedade em conta de participação à pessoa jurídica. 



\begin{abstract}
SILVA, Fabiana Carsoni Alves Fernandes da. Silent Partnership under tax law - IRPJ, CSL, PIS and COFINS. 2020. 312 f. Dissertação (Mestrado em Direito Econômico, Financeiro e Tributário) - Faculdade de Direito, Universidade de São Paulo, São Paulo, 2020.
\end{abstract}

This dissertation sets out to analyze the applicable tax regime for the results from the operations of Sociedades em Conta de Participação (SCP) or Silent Partnerships with respect to Corporate Income Tax (IRPJ), Social Contribution Tax on Profits (CSL), Social Integration Program Contribution Tax (PIS) and Social Security Financing Contribution Tax (COFINS). To this end, it examines the nature, the legal basis and the essential characteristics of Silent Partnerships. It also examines the relationship between private law and tax law, investigating whether the latter may attribute distinct effects to the legal institutes created and regulated by the former. Later, it outlines the history of taxation of earnings, revenue and profits arising from the operations of Silent Partnerships, demonstrating that, with the enactment of art. 7 of Law Decree no. 2,303, on Nov., 21, 1986, such partnerships were equated with legal entities for tax collection purposes, a status that extends to the calculation of CSL and of PIS and COFINS under the cumulative regime. Though the validity of this equating is subject of debate, the dissertation clarifies that said status constitutes the criteria for calculation of IRPJ, CSL, PIS and COFINS under the cumulative regime and was established in an attempt to improve tax regulation compliance controls. It also demonstrates that this status satisfies the requirements of arts. 109 and 126 of the National Tax Code (CTN), in addition to neither violating nor distorting the private law legal framework which Silent Partnerships are subject to, with their nature, legal basis and essential characteristics preserved. The dissertation also explains that, as a result of this criteria for the collection of IRPJ, CSL, PIS and COFINS under the cumulative regime, which follows from the equating of Silent Partnerships with legal entities, the financial results of such partnerships must be taxed separately under one of the possible regimes for the taxation of legal entity income and revenue, and not be mixed in with the financial results of the general (ostensive) partner obtained from the operations of the Silent Partnership.

Keywords: Sociedade em Conta de Participação or Silent Partnership. Nature, legal basis and essential characteristics under private law. Relationship between private law and tax law. IRPJ, CSL, PIS and COFINS tax regime. Equating of Silent Partnership with legal entities. 



\section{GLOSSÁRIO}

ADI

ADI CST

ADI SRF

ART

CARF

CC

CCRJ

CFC

CGC

CIDE

CNPJ

CSL

CST

COFINS

COSIT

CPC

CPC/15

CPC/73

CPRB

CVM

ECD

ECF

EFD-Contribuições Escrituração Fiscal Digital das Contribuições incidentes sobre a Receita

EMBRATUR

FATF

IFRS

Ação Direta de Inconstitucionalidade

Ato Declaratório Interpretativo da Coordenação-Geral do Sistema de Tributação

Ato Declaratório Interpretativo da Secretaria da Receita Federal Artigo(s)

Conselho Administrativo de Recursos Fiscais

Conselho de Contribuintes

Conselho de Contribuintes do Município do Rio de Janeiro

Conselho Federal de Contabilidade

Cadastro Geral de Contribuintes

Contribuição de Intervenção do Domínio Econômico (Lei n. 10168, de 29.12.2000)

Cadastro Nacional de Pessoas Físicas

Contribuição Social sobre o Lucro

Coordenação-Geral do Sistema de Tributação

Contribuição para o Financiamento da Seguridade Social

Coordenação-Geral de Tributação

Comitê de Pronunciamentos Contábeis

Código de Processo Civil de 2015 (Lei n. 13105, de 16.03.2015)

Código de Processo Civil de 1973 (Lei n. 5869, de 11.01.1973)

Contribuição previdenciária sobre a receita bruta

Comissão de Valores Mobiliários

Escrituração Contábil Digital

Escrituração Contábil Fiscal

Instituto Brasileiro de Turismo, autarquia especial do Ministério do Turismo

Financial Action Task Force

International Financial Reporting Standards 
ICMS

IOF

IPI

IRPF

IRPJ

IRRF

ISS

JCP

LINDB

MEP

PIS

RET

RFB

RIR/18

RIR/99

SCP

Simples Nacional

SPE

SPED

SRF

STF

STJ

TJRS

TRF1
Imposto sobre operações relativas à circulação de mercadorias e prestação de serviços de transporte interestadual e intermunicipal e de comunicação

Imposto sobre operações de crédito, câmbio, seguros e títulos e valores mobiliários

Imposto sobre Produtos Industrializados

Imposto de Renda da Pessoa Física

Imposto de Renda da Pessoa Jurídica

Imposto de Renda Retido na Fonte

Imposto Sobre Serviços de Qualquer Natureza

Juro(s) sobre o Capital Próprio

Lei de Introdução à Normas do Direito Brasileiro (Decreto-lei n. 4657, de 04.09.1942)

Método da Equivalência Patrimonial

Programa de Integração Social

Regime Especial de Tributação

Secretaria da Receita Federal do Brasil

Regulamento do Imposto de Renda de 2018 (Decreto n. 9580, de 22.11.2018)

Regulamento do Imposto de Renda de 1999 (Decreto n. 3000, de 26.03.1999)

Sociedade(s) em Conta de Participação

Regime especial unificado de arrecadação de tributos e contribuições devidos pelas microempresas e empresas de pequeno porte (Lei Complementar n. 123, de 14.12.2006)

Sociedade Propósito Específico

Sistema Público de Escrituração Digital

Secretaria da Receita Federal

Supremo Tribunal Federal

Superior Tribunal de Justiça

Tribunal de Justiça do Estado do Rio Grande do Sul

Tribunal Regional Federal da $1^{\mathrm{a}}$ Região 


\section{SUMÁRIO}

1 INTRODUÇÃO

2 A SCP, SUA ORIGEM, SUA NATUREZA E SUA CAUSA JURÍDICA ............. 27

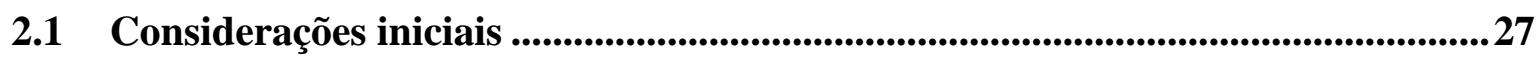

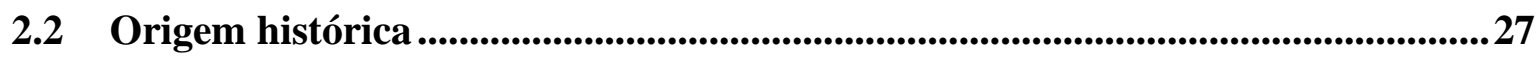

2.3 A conta de participação em outros países .......................................................30

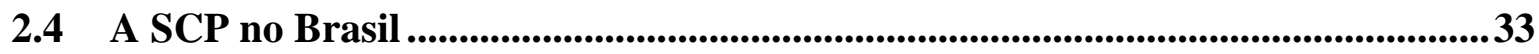

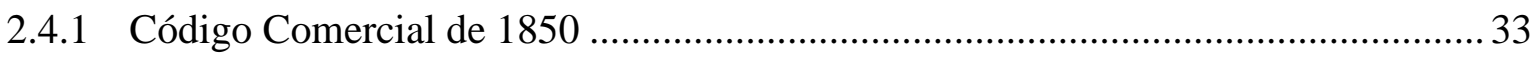

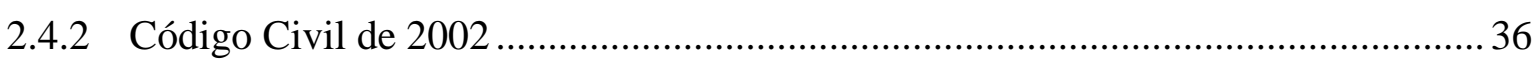

2.4.3 Projeto de Lei da Câmara dos Deputados n. 1572, de 2011, que institui o Código Comercial, e o Projeto de Lei do Senado Federal n. 487, de 2013, que altera o Código Comercial ................................................................................. 40

2.4.4 A natureza e a causa jurídica da SCP.............................................................. 44

2.4.4.1 O contrato de SCP enquanto sociedade não personificada ...............................45

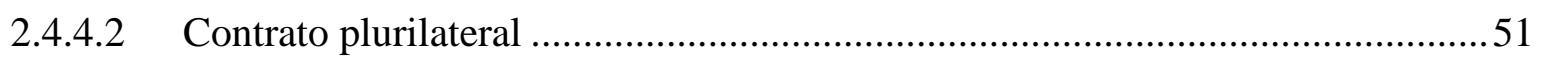

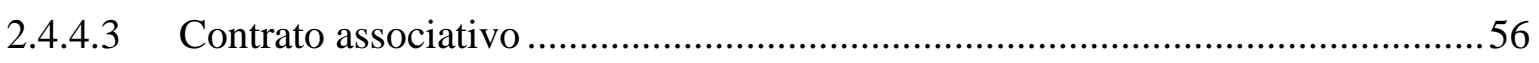

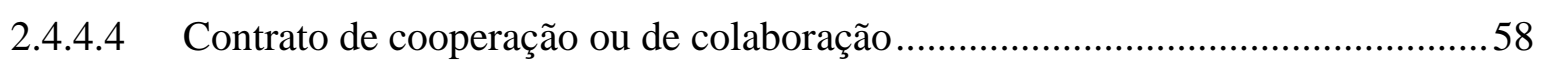

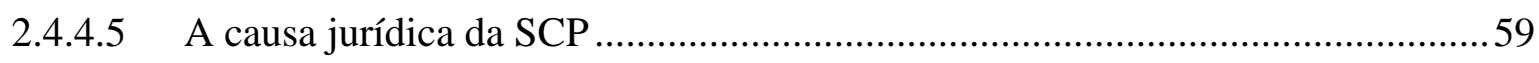

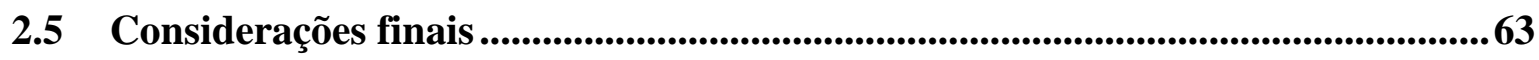

3 A SCP E SUAS CARACTERÍSTICAS ESSENCIAIS...........................................65

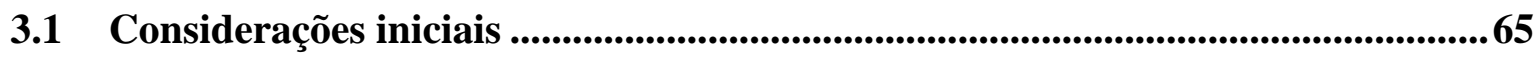

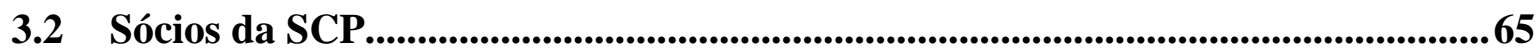

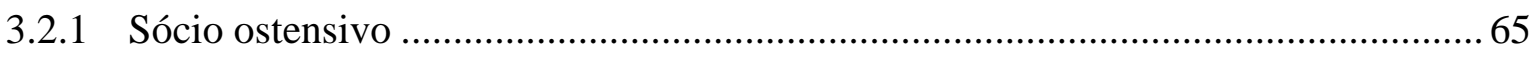

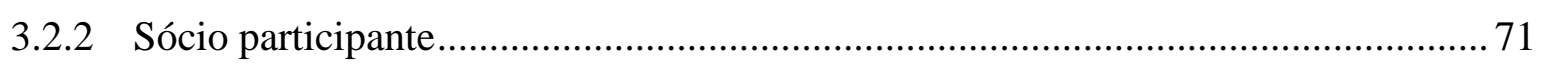

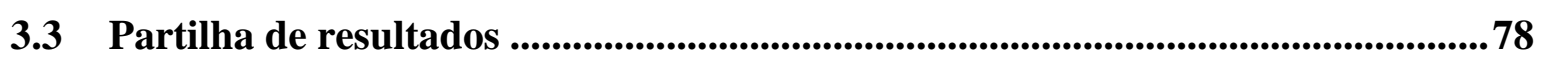

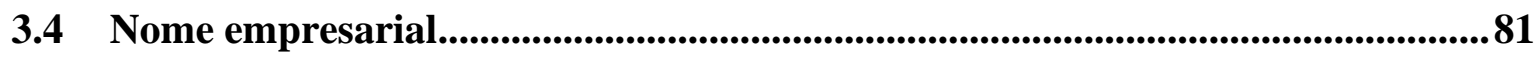

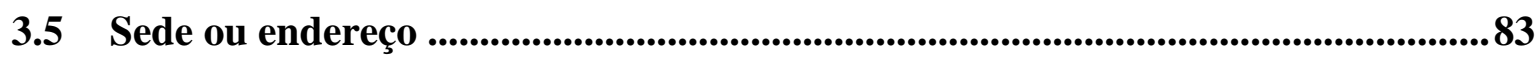

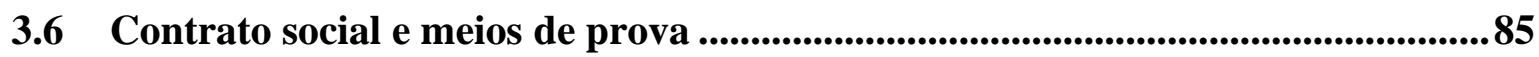

3.7 Relação com terceiros ..........................................................................................90

3.8 Capital social......................................................................................................91

3.9 Fundo social (patrimônio especial) ............................................................95

3.10 Considerações finais .............................................................................................104 
4 A RELAÇÃO ENTRE O DIREITO PRIVAdo E O DIREITO TRIBUTÁRIO_...............................................................................................................107

4.1 Considerações iniciais..................................................................................107

4.2 Os antecedentes à promulgação do CTN..............................................................107

4.3 As diferentes formas de relacionamento entre o Direito Tributário e o

Direito Privado............................................................................................................118

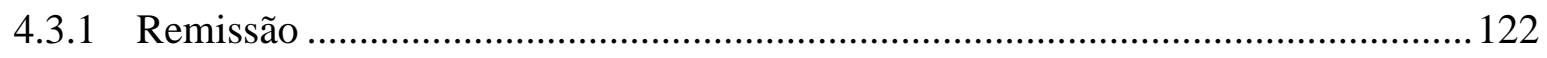

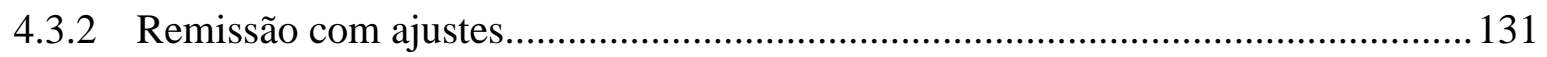

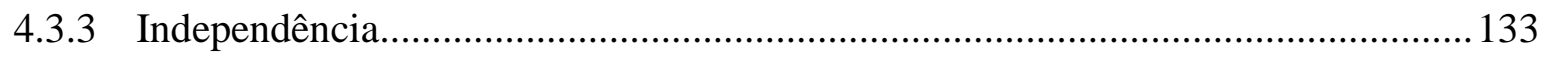

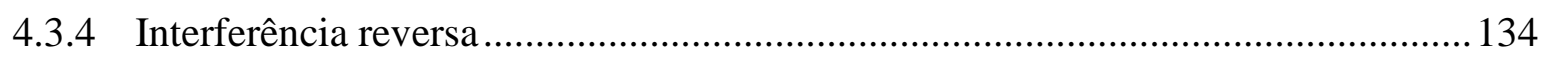

4.4 Considerações finais .............................................................................................135

5 O REGIME TRIBUTÁRIO DA SCP: HISTÓRICO E EQUIPARAÇÃo À PESSOA JURÍDICA PARA EFEITO DE APURAÇÃO DO IRPJ, DA CSL, DA CONTRIBUIÇÃO AO PIS E DA COFINS .....................................................137

5.1 Considerações iniciais...............................................................................137

5.2 Decreto-lei n. 1134, de 16.11.1970 ..............................................................................137

5.3 Parecer Normativo CST n. 345, de 19.05.1971 ..........................................................140

5.4 Decreto-lei n. 2303, de 21.11.1986 ...........................................................................146

5.5 A sujeição passiva na SCP ......................................................................................163

5.6 A inscrição no CNPJ.........................................................................................167

5.7 A escrituração das operações da SCP em livros comerciais...................................184

5.7.1 O dever do sócio ostensivo de escriturar as operações da SCP .............................. 184

5.7.2 A forma de escrituração das operaç̃os de SCP ...................................................... 186

5.7.2.1 Negócios não controlados em conjunto. O princípio contábil da entidade ........186

5.7.2.2 O negócio sujeito a controle conjunto. O veículo separado .................................195

5.7.3 A escrituração das operaç̃oes da SCP para fins tributários ...................................... 199

5.8 As metodologias de avaliação de investimento (MEP e método do custo) .........205

5.9 Considerações finais .......................................................................................................211

6 APURAÇÃO do IRPJ, DA CSL, DA CONTRIBUIÇÃO AO PIS E DA COFINS INCIDENTES SOBRE OS RESULTADOS E OPERAÇÕES DA SCP.

6.1 Consideraç̃̃es iniciais...............................................................................................213

6.2 IRPJ e CSL ........................................................................................................213 
6.2.1 A compensação de prejuízo fiscal e base de cálculo negativa da CSL

6.2.2 A restituição em espécie, a compensação de indébitos e a dedução de valores retidos na fonte a título de imposto de renda e de CSL

6.2.3 Incentivos fiscais

6.2.4 O regime de tributação da renda e dos proventos de qualquer natureza da SCP ... 218

6.2.4.1 Análise de caso: uso da SCP para segregar resultados e viabilizar a adoção do lucro presumido (acórdão n. 1402-002685, de 26.07.2017)

6.2.4.2 Análise de caso: uso da SCP para segregar resultados e viabilizar a adoção do lucro presumido (acórdão n. 1201-002686, de 11.12.2018)

6.2.5 Devolução de bens e direitos relativos à SCP. 230

6.2.6 Os rendimentos vinculados à SCP distribuídos aos sócios ..... 231

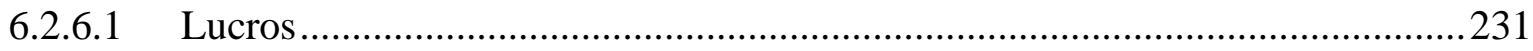

6.2.6.2 Pagamento ou crédito de JCP aos sócios da SCP...........................................232

6.2.7 Qualificação da SCP ou de seus sócios como parte ligada ou vinculada ..............237

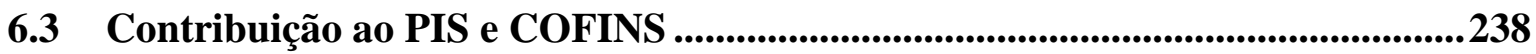

6.4 Normas aplicáveis ao imposto de renda, à CSL, à contribuição ao PIS e à COFINS.

6.4.1 A partilha de resultados na SCP: a isenção do imposto de renda, da CSL, da contribuição ao PIS e da COFINS sobre os lucros ou dividendos distribuídos aos sócios

6.4.1.1 Análise de caso: a desqualificação da SCP e a tributação dos lucros como contraprestação de serviços (acórdão n. 1103-001052, de 07.05.2014)

6.4.1.2 Análise de caso: uso da SCP para segregar resultados, viabilizar a distribuição de lucros isentos e impedir a aplicação do adicional de IRPJ de 10\% (Solução de Consulta COSIT n. 142, de 19.09.2018).

6.4.2 ADI SRF n. 14, de 04.05.2004: pool hoteleiro

6.4.2.1 Análise de caso: a qualificação de contrato de prestação de serviços como SCP em decorrência do ADI SRF n. 14/04 (acórdão n. 1202-001011, de 07.08.2013). 
DECISÕES JUDICIAIS E ADMINISTRATIVAS E PRONUNCIAMENTOS ADMINISTRATIVOS .........................................................................................305 


\section{INTRODUÇÃO}

A SCP é uma sociedade sem personalidade jurídica, que possui eficácia interna, é dizer, entre seus sócios, e não para terceiros, tendo um sócio empreendedor (ostensivo), que emprega em seu nome os bens, serviços e recursos que lhe são próprios e/ou que lhe são confiados por outro sócio (participante), sendo os resultados do empreendimento repartidos entre os sócios. ${ }^{1}$

Como a SCP é uma sociedade interna, é dizer, eficaz somente entre seus sócios, é comum que não se tenha notícia de seu uso, tampouco conhecimento de sua existência. Mesmo assim, sabe-se haver massiva utilização da conta de participação para viabilizar os mais diversos empreendimentos em diferentes setores da economia. ${ }^{2}$

Com efeito, a conta de participação é largamente utilizada como instrumento de aglutinação de interessados, sejam pessoas físicas, jurídicas ou mesmo entes despersonalizados $^{3}$, com vistas ao desenvolvimento de empreendimentos, nos quais ao menos um dos sócios não deseja interagir com o mercado.

Uma das justificativas para o grande uso da SCP como instrumento de aglutinação de interessados no desenvolvimento dos mais variados negócios decorre de o referido instituto não ser dotado da mesma complexidade de outras sociedades, sendo seus elementos característicos a simplicidade, a informalidade, a dinamicidade e a flexibilidade. ${ }^{4}$ Trata-se, nesse contexto, de um tipo societário maleável e de rápida constituição, não se submetendo a registros demandados a outros tipos societários. ${ }^{5}$

A maleabilidade da SCP, aliada ao fato de que a sociedade é eficaz somente entre seus sócios, permite que tal instituto seja explorado pela imaginação e engenhosidade de juristas, investidores e empresários no desenvolvimento de negócios, conferindo à SCP a

1 SCALZILLI, João Pedro; SPINELLI, Luis Felipe. Sociedade em conta de participação. São Paulo: Quartier Latin, 2015, p. 50.

2 Ibid., p. 287.

3 Entes despersonalizados, ou desprovidos de personalidade jurídica, a que ora nos referimos, e ao qual faremos referência em outras passagens deste trabalho, são "entidades com muitas das características das pessoas jurídicas, mas que não chegam a ganhar sua personalidade [...]. Na maioria dessas entidades existe, na verdade, uma capacidade ou personalidade diminuída ou restrita" (VENOSA, Sílvio de Salvo. Direito Civil: parte geral. 8. ed. São Paulo: Atlas, 2008, p. 237-238). É o caso, por exemplo, das próprias SCP, dos condomínios edilícios, dos consórcios, do espólio e da massa falida.

4 SCALZILLI, João Pedro; SPINELLI, Luis Felipe, op. cit., p. 31.

5 GALIZZI, Gustavo Oliva. A sociedade em conta de participação como subespécie do gênero joint venture. Revista de Direito Mercantil - Industrial, Econômico e Financeiro, São Paulo, n. 135, 2004, p. 216. 
virtuosidade necessária a que seja aplicada a uma gama extensa de empreendimentos em um mercado competitivo e sofisticado. ${ }^{6}$

O presente estudo historiará o regime de tributação aplicável aos rendimentos, receitas e ganhos oriundos de negócios empreendidos por meio de SCP, demonstrando que, com a edição do Decreto-lei n. 2303, de 21.11.1986 (art. $7^{\circ}$ ), a SCP foi equiparada à pessoa jurídica para efeito de apuração do imposto de renda, equiparação essa que é extensível à CSL e à contribuição ao PIS e à COFINS devidas no regime cumulativo.

Buscar-se-á demonstrar se, com a equiparação à pessoa jurídica, a SCP deixou de ser um instrumento simples, informal, dinâmico, flexível e virtuoso. Para tanto, investigaremos a validade da equiparação e os limites do legislador tributário na atribuição de efeitos distintos a instituto disciplinado pelo Direito Privado.

Ver-se-á neste estudo que se discute a validade da norma de equiparação da SCP à pessoa jurídica, notadamente porque a legislação tributária exige o cumprimento de certas formalidades dispensadas pelo Direito Privado, como a apresentação de documento comprobatório da existência da sociedade, imprimindo menos simplicidade a um tipo societário marcado pela maleabilidade. O entrechoque entre a disciplina de Direito Privado e a de Direito Tributário das SCP, inaugurada com a edição do Decreto-lei n. 2303/86 (art. $\left.7^{\circ}\right)$, conduziu alguns autores a afirmar que a norma tributária de equiparação seria ilegal. ${ }^{7}$

Os debates em torno da validade da equiparação foram reacesos quando a RFB determinou, em 2014, a inscrição da SCP no $\mathrm{CNPJ}^{8}$. A partir dessa exigência, alguns autores sustentaram que a referida inscrição teria atribuído personalidade jurídica à SCP, ferindo, assim, as normas de regência do instituto, ditadas pelo Direito Privado. ${ }^{9}$

Se, por um lado, é lícito que a conta de participação seja oculta do ponto de vista privado, no campo tributário, diferentemente, é fundamental que o fisco possa identificá-la e que, portanto, tenha mecanismos para fiscalizar o adequado cumprimento da legislação

6 ALMEIDA, Carlos Guimarães de. A virtuosidade da sociedade em conta de participação. Revista de Direito Mercantil, Industrial, Econômico e Financeiro, São Paulo, n. 8, 1972, p. 63.

7 Nesse sentido, vide: COSTA, José Maria da. A sociedade em conta de participação no direito de empresa do código civil de 2002. 2006. 310 f. Dissertação (Mestrado em Direito Civil) - Pontifícia Universidade Católica de São Paulo, São Paulo, 2006, p. 258. Para a verificação da opinião de outros autores, referimo-nos às considerações sobre o tema feitas no Capítulo 5.

8 Quando da equiparação da SCP à pessoa jurídica promovida pelo art. $7^{\circ}$ do Decreto-lei n. 2303/86, a SRF, na regulamentação do tema, determinou sua inscrição no anterior CGC, nos termos da Instrução Normativa SRF n. 49/87. Meses depois, no entanto, a Instrução Normativa SRF n. 179/87 revogou tal determinação, a qual somente foi retomada em 2014, como será historiado no Capítulo 5.

9 Nesse sentido, vide: MORAES, Francisco Chagas de. A equiparação da sociedade em conta de participação à pessoa jurídica. Suplemento Tributário da Revista LTr, São Paulo, v. 65, 1987, p. 364. Para a verificação da opinião de outros autores, referimo-nos às considerações sobre o tema feitas no Capítulo 5. 
tributária. Por isso é que a RFB criou diversos mecanismos de controle da conta de participação. Um deles é a exigência de que essa sociedade promova sua inscrição no CNPJ. A obrigação - que existe para outros entes desprovidos de personalidade jurídica, como o consórcio e o condomínio edilício - carrega uma série de outras exigências, como a apresentação de declarações individualizadas e apuração segregada de créditos e débitos.

Nesta dissertação, analisar-se-á se a legislação tributária deve obedecer a limites mínimos ao atribuir efeitos distintos a institutos de Direito Privado, como ocorre com a equiparação das SCP à pessoa jurídica ou se possui ampla flexibilidade para fazê-lo. Verificar-se-á se - e em qual medida - a interferência do Direito Tributário nas normas de Direito Privado é autorizada pelo ordenamento jurídico.

Para viabilizar o estudo da legislação tributária que equipara a SCP à pessoa jurídica, será necessário investigar o regime societário a que tal instituto está submetido, bem como investigar a interação entre as normas societárias e tributárias aplicáveis àquelas sociedades.

As considerações do parágrafos anteriores revelam a interdisciplinaridade do tema, já que a compreensão das normas que dispõem sobre a tributação dos resultados e operações da SCP não se esgota pelo estudo do Direito Tributário, passando pelo exame da natureza, da causa jurídica ${ }^{10}$ e das características essenciais do instituto, todas elas hauridas do Direito Privado, além de igualmente passar pela análise do relacionamento deste ramo com o Direito Tributário.

Muito embora diversos estudos sobre a conta de participação já tenham sido publicados desde sua instituição, no Brasil, pelo Código Comercial de 1850, pouca foi a contribuição da comunidade jurídica em torno dos aspectos fiscais desta figura societária. Daí a importância do presente trabalho, tendo esta dissertação o objetivo, fundamentalmente, de agregar ao estudo e à compreensão do regime tributário a que se submete a SCP em matéria de IRPJ, CSL, contribuição ao PIS e COFINS.

O ponto de partida deste trabalho consistirá na investigação da origem e da natureza jurídica da conta de participação. Analisar-se-á a legislação comparada, o que contribuirá para a compreensão da natureza jurídica da conta de participação em outros

10 Neste trabalho, consideramos causa jurídica como a razão econômico-jurídica do negócio, sua finalidade, ou função prática, em garantia da qual o direito concede sua tutela, como ensina Luís Eduardo Schoueri (Normas tributárias indutoras e intervenção econômica. Rio de Janeiro: Forense, 2005, p. 133). Voltaremos a tratar do conceito de causa jurídica adiante, quando analisarmos a função prática da SCP. 
países ${ }^{11}$ e também para sua comparação com o tratamento que foi dado ao referido instituto no Brasil.

Demonstraremos, no Capítulo 2, que a SCP surgiu no exterior como instrumento negocial apto a permitir que um de seus sócios não seja conhecido do público. Diante do uso crescente do instituto, operou-se sua regulamentação em diversos países, inclusive no Brasil.

A conta de participação não tem tratamento uniforme na legislação comparada, como será esclarecido no Capítulo 2. Ora ela é tratada como contrato sujeito à disciplina afeta aos contratos em geral, ora é tratada como um tipo societário desprovido de personalidade jurídica.

No Brasil, desde a codificação de 1850, veiculada pelo Código Comercial, a conta de participação é considerada uma sociedade, o que se repete no Código Civil de 2002. Em que pese há mais de um século a SCP seja qualificada, no Brasil, como tipo societário, há divergência doutrinária em torno de sua natureza jurídica. Prova disso é que o Projeto de Lei n. 1572, de 2011, que pretende instituir um novo Código Comercial, revogando parte das disposições do Código Civil de 2002, qualifica a conta de participação como contrato de investimento conjunto, situando-a dentre os contratos empresariais, e não dentre os tipos societários. $^{12}$

Ainda no Capítulo 2, demonstraremos que, não obstante os debates teóricos sobre a natureza jurídica da SCP, o legislador disciplinou-a como contrato de sociedade. Ser contrato de sociedade significa dizer, como se verá no mesmo capítulo, que a SCP é contrato plurilateral, associativo, de cooperação ou de colaboração. Encerraremos o Capítulo 2 tratando da causa jurídica da SCP.

Uma vez delimitado que a conta de participação, no Brasil, constitui uma sociedade, demonstrar-se-á no Capítulo 3 que ela não se sujeita a diversas normas atinentes às sociedades personificadas. De fato, dada a ausência de personalidade jurídica da conta de participação, algumas das regras de regência das sociedades personificadas não são a ela aplicáveis. É o caso, por exemplo, das normas que disciplinam os requisitos mínimos do contrato social, o capital social, a sede e o nome empresarial e a autonomia patrimonial. Ver-se-á que, sendo desprovida de personalidade jurídica, e tendo eficácia entre seus

11 Analisaremos o tratamento conferido à conta de participação nos seguintes países: Itália, Espanha, Portugal, Alemanha, Argentina, França, Estados Unidos da América e Inglaterra.

12 BRASIL. Projeto de Lei n. 1572, de 2011. Brasília: Câmara dos Deputados, 2011. Disponível em: $<$ http://www.camara.gov.br/proposicoesWeb/prop_mostrarintegra?codteor=888462\&filename=PL+1572/ 2011>. Acesso em: 22 jul. 2018. 
sócios, a SCP não se relaciona com terceiros, não é titular de direitos e obrigações e, portanto, não possui patrimônio próprio, tampouco possui capital social, sede, endereço ou nome empresarial.

Delimitadas a causa e a natureza jurídica da SCP e suas características essenciais, analisaremos, no Capítulo 4, se o Direito Tributário é um ramo do Direito autônomo em relação aos demais, se está limitado aos ditames do Direito Privado ou se convive paralelamente com os demais ramos do Direito, inclusive com o Direito Privado. Isso nos permitirá verificar se a legislação tributária está submetida aos princípios, conceitos e regras de Direito Privado ou se pode desprezá-los em determinadas situações.

A análise do relacionamento entre o Direito Tributário e o Direito Privado é importante para o presente trabalho, porque, como mencionado, não obstante a SCP, do ponto de vista do Direito Civil, seja uma sociedade desprovida de personalidade jurídica, o art. $7^{\circ}$ do Decreto-lei n. 2303, de 21.11.1986, equiparou-a, para fins de imposto de renda, à pessoa jurídica, o que é extensível à CSL e à contribuição ao PIS e à COFINS devidas no regime cumulativo.

Diante disso, faz-se necessário avaliar se o ordenamento jurídico convive com a dissonância entre os tratamentos atribuídos àquele instituto pelo Direito Civil e pelo Direito Tributário e, em caso positivo, os limites a que se sujeita o legislador tributário.

Assim, no Capítulo 4, analisaremos a relação entre o Direito Privado e o Direito Tributário, analisando também os contornos dados à matéria pelos art. 109 e 110 do CTN, o que faremos, inicialmente, pela exposição dos debates que antecederam a promulgação do CTN para, em seguida, examinar as diferentes formas de relacionamento entre o Direito Privado e o Direito Tributário, demonstrando que a legislação tributária pode adotar as seguintes soluções frente a institutos de Direito Privado: a) remissão; b) remissão com ajustes; c) independência; e d) interferência reversa. ${ }^{13}$

A demonstração do relacionamento entre o Direito Tributário e o Direito Privado permitirá identificar, ao final desta dissertação, se a norma tributária que determina a equiparação da SCP à pessoa jurídica é compatível com o ordenamento jurídico, notadamente com a disciplina do instituto dada, em um primeiro momento, pelo Código Comercial de 1850 e, posteriormente, pelo Código Civil de 2002, verificando se a equiparação padece de vícios ou irregularidades como sustentado por parte da doutrina.

13 As quatro soluções são apontadas por Luís Flávio Neto (NETO, Luís Flávio. Entre o amor e a indiferença: vamos discutir a relação? O relacionamento do direito tributário com o direito privado e o caso da permuta de ações sem torna. Revista Direito Tributário Atual, São Paulo: IBDT, v. 38, 2017, p. 93, 9498). Todas elas serão explicadas no Capítulo 4. 
No Capítulo 5, após historiarmos as primeiras normas tributárias que trataram da SCP em matéria de imposto de renda, analisaremos a equiparação da SCP à pessoa jurídica determinada pelo art. $7^{\circ}$ do Decreto-lei n. 2303/86, explicando sua justificativa e seus principais efeitos. Investigaremos se, com a equiparação, a SCP tornou-se sujeito passivo da obrigação tributária, para o que serão relevantes as conclusões alcançadas no Capítulo 4 sobre o relacionamento entre o Direito Tributário e o Direito Privado, bem como o exame do art. 126 do CTN, segundo o qual a capacidade tributária passiva independe da capacidade civil das pessoas naturais; de achar-se a pessoa natural sujeita a medidas que importem privação ou limitação do exercício de atividades civis, comerciais ou profissionais, ou da administração direta de seus bens ou negócios; de estar a pessoa jurídica regularmente constituída, bastando que configure uma unidade econômica ou profissional.

Também no Capítulo 5, serão analisadas as obrigações tributárias acessórias ${ }^{14}$ instituídas pela RFB com fundamento no art. 113, parágrafo $2^{\circ}$, do $\mathrm{CTN}$ após a equiparação da SCP à pessoa jurídica, notadamente o dever de inscrição no CNPJ e o dever de apresentação de registros contábeis e fiscais próprios da SCP, apartados dos assentamentos do sócio ostensivo.

No tocante ao CNPJ, investigaremos se as normas editadas pela RFB são compatíveis com o ordenamento jurídico, seja em relação aos limites de que dispõem as autoridades fiscais para normatizar deveres instrumentais, seja em relação a possível ofensa das referidas normas ao regime jurídico da SCP disciplinado no Código Civil de 2002.

Quanto ao tema afeto à escrituração das operações e dos resultados da SCP, examinaremos no Capítulo 5 se a elaboração de registros contábeis próprios e separados para a SCP é uma exigência da Ciência Contábil ou se tem natureza de obrigação tributária acessória.

Ainda no Capítulo 5, analisaremos se os sócios da SCP devem avaliar seu investimento na sociedade por alguma das metodologias previstas para tanto na lei

14 A expressão obrigação tributária acessória é muito criticada pela doutrina, seja porque não existe dita acessoriedade, seja porque não se trata de uma obrigação de conteúdo patrimonial, como ocorre no Direito Privado. É por isso que aquela expressão tem sido, comumente, substituída por dever instrumental ou de contorno (nesse sentido, vide: CARVALHO, Paulo de Barros. A relação jurídica tributária e as impropriamente chamadas 'obrigações acessórias'. Revista de Direito Público, São Paulo: Revista dos Tribunais, n. 17, p. 381-386, 1971; e SCHOUERI, Luís Eduardo. Direito Tributário. 8. ed. São Paulo: Saraiva, 2018, p. 501-505). Adiante, adotaremos ambas as expressões, até porque, independentemente das críticas que mereça, o art. 113, parágrafo $2^{\circ}$, do CTN acolheu a nomenclatura obrigação tributária acessória. 
societária (Lei n. 6404, de 15.12.1976), perquirindo se a equiparação da SCP à pessoa jurídica para fins de imposto de renda teria o condão de impor aos sócios a avaliação de seu investimento independentemente das normas de regência do tema contidas na lei societária.

Estabelecidos os contornos e a justificativa da equiparação da SCP à pessoa jurídica, apresentaremos, no Capítulo 6, os efeitos oriundos do regime instituído pelo art. $7^{\circ}$ do Decreto-lei n. 2303/86, criado para o imposto de renda, mas estendido, também, à CSL e à contribuição ao PIS e à COFINS devidas no regime cumulativo.

Para demonstrar os efeitos da equiparação no cálculo do IRPJ, da CSL e da contribuição ao PIS e da COFINS devidas no regime cumulativo, além de mencionar e explicar as normas que disciplinam a matéria, no Capítulo 6, faremos referência a pronunciamentos das autoridades fiscais da RFB, assim como procederemos à análise de casos apreciados pelo CARF e pela RFB versando sobre a tributação de SCP.

O trabalho será realizado com base nos métodos hipotético-dedutivo, bibliográfico e dissertativo-argumentativo. Além disso, para o desenvolvimento das questões a serem enfrentadas neste trabalho, utilizaremos o método histórico, pelo qual será apresentada a evolução do tratamento societário e tributário da SCP; o método comparativo, com base na verificação de situações análogas na legislação tributária; e indutivo, pela análise de decisões administrativas e judiciais que elucidem o tratamento tributário conferido à SCP em decorrência da equiparação.

Como este trabalho analisará se a equiparação da sociedade à pessoa jurídica, determinada pelo art. $7^{\circ}$ do Decreto-lei n. 2303/86, padece de algum vício ou irregularidade, sendo a equiparação aplicável ao IRPJ, à CSL e à contribuição ao PIS e à COFINS devidas no regime cumulativo, mas não a outros tributos, não abordaremos o regime tributário e a forma de apuração de outros tributos incidentes sobre as operações da SCP.

Além disso, não será analisado de forma detalhada o tratamento conferido à conta de participação em outros países, mais precisamente na Itália, Espanha, Portugal, Alemanha, Argentina, França, Estados Unidos da América e Inglaterra. A referência que se fará ao direito comparado será útil, apenas, para a identificação das controvérsias em torno da natureza jurídica do instituto e, assim, para a compreensão e contextualização do regime jurídico atribuído pelo legislador pátrio à SCP.

A presente dissertação será elaborada com base em bibliografias estrangeira e nacional que abordam o tema na perspectiva do Direito Tributário e do Direito Privado, 
mais especificamente em livros, artigos em periódicos, dissertações de mestrado e teses de doutorado.

Este trabalho também será realizado mediante análise de decisões administrativas e judiciais que abordam o tema na perspectiva do Direito Tributário e do Direito Privado, bem como mediante análise de atos e decisões das autoridades fiscais, inclusive de soluções de consultas, relacionados à matéria.

Ao final deste estudo, após esclarecer o regime tributário a que se sujeita a SCP em matéria de IRPJ, CSL, contribuição ao PIS e COFINS, pretende-se demonstrar se ele padece de vícios ou irregularidades, quer frente a normas de Direito Tributário, quer frente a normas de Direito Privado, ou se, a despeito de válido, ele desencoraja o uso do instituto, retirando-lhe a simplicidade, a informalidade, a dinamicidade, a flexibilidade e a virtuosidade. 


\section{CONCLUSÃO}

Neste trabalho, demonstramos que a SCP constitui modalidade associativa, destituída de personalidade jurídica, que se perfaz mediante contrato, celebrado entre seus sócios, os quais conjugam aptidões, recursos e esforços, de tal sorte a viabilizar que o sócio ostensivo, externamente, e sob seu nome individual, obrigue-se junto a terceiros, desempenhando a atividade constitutiva do objeto social da sociedade.

No Capítulo 2, viu-se haver controvérsia, no Brasil e no exterior, sobre a natureza jurídica da SCP. Demonstramos que, embora haja quem lhe atribua a natureza de contrato de investimento ou de participação, refutando seu caráter societário, para nós, entre seus sócios, isto é, internamente, a SCP é contrato de sociedade, como declarado pelo Código Civil de 2002 e pelo Código Comercial de 1850.

A SCP constitui contrato de sociedade, na medida em que une pessoas dedicadas e dirigidas a um fim comum, para o que elas estabelecem direitos e deveres recíprocos, mediante conjugação de esforços, recursos e aptidões, tudo de modo a que, afinal, partilhem os lucros e prejuízos da atividade.

Ser contrato de sociedade significa dizer, por decorrência, que a SCP é contrato plurilateral, associativo, de cooperação e colaboração.

O contrato de SCP é acordo de caráter plurilateral, porque as partes se associam, cooperando entre si mediante união de esforços, aptidões, bens e recursos em busca de um objetivo comum, consistente na realização do empreendimento, em nome e sob a exclusiva responsabilidade do sócio ostensivo. Há, pois, direitos e obrigações recíprocos de todos e entre todos os sócios, que convergem em torno do escopo comum.

A SCP é também um contrato associativo ou de organização. Essa categorização, como se demonstrou neste trabalho, aparece em substituição à divisão dos contratos em plurilaterais e bilaterais (teoria contratualista), pois tal divisão, de acordo com os defensores do contrato associativo, seria meramente formal, mostrando-se insuficiente para a compreensão e regulação do fenômeno societário, o qual não se resolveria pela identificação de um escopo comum ou pela aplicação de princípios e conceitos próprios da teoria geral dos contratos. Mesmo que se refute a qualificação da sociedade como um contrato plurilateral, para situá-la entre os contratos associativos ou de organização, a SCP enquadra-se como tal, e não como contrato de escambo ou de troca. De fato, a SCP inserese dentre os contratos associativos, porque nela identifica-se uma organização interna - 
nunca externa - formada entre os sócios, que coordenam seus atos com vistas a uma mesma direção final.

A SCP é, ainda, um contrato de cooperação e colaboração. É que os sócios da SCP nutrem um pensamento de cooperação econômica, reunindo-se e congregando trabalho, bens, serviços, recursos ou expertise em busca de um escopo comum, qual seja, a consecução do empreendimento, que é realizada, externamente, em nome do sócio ostensivo.

A causa jurídica das SCP é a persecução do fim comum almejado pelas partes, o qual consiste no desenvolvimento de um ou mais negócios, mediante esforços empreendidos pelo sócio ostensivo junto ao mercado, com vistas à obtenção de lucro para sua posterior partilha com o sócio participante. Quer dizer, nas SCP, os sócios perseguem um fim comum, sob a condição de que um deles (sócio participante) não se obrigue perante terceiros, participando, contudo, dos lucros apurados pela outra parte (sócio ostensivo) e partilhando eventuais perdas, ambos - lucros e perdas - decorrentes do exercício da atividade econômica objeto da sociedade, sem a criação de um novo ente dotado de personalidade jurídica e de personalidade patrimonial.

Após analisarmos, no Capítulo 2, a natureza e a causa jurídica da SCP, no Capítulo 3, examinamos o regime jurídico a que se submete a referida sociedade, demonstrando suas características essenciais, expondo a função dos sócios ostensivo e participante, a forma de partilha de resultados, a ausência de capital social, de nome empresarial, de sede ou de endereço e de autonomia patrimonial da sociedade, bem como a relação dos sócios com terceiros.

Esclareceu-se que, por força da equiparação da SCP à pessoa jurídica para fins de apuração do IRPJ, da CSL, da contribuição ao PIS e da COFINS, poder-se-ia imaginar que algumas dessas características essenciais deixaram de ser observadas pela RFB quando da regulamentação da norma de equiparação. Demonstrou-se nos Capítulos 3 e 5, no entanto, que as normas editadas pela RFB preservam a natureza, a causa jurídica e as características essenciais da SCP.

No Capítulo 3, foi visto que, tanto no regime do Código Comercial de 1850, como no do Código Civil de 2002, o sócio ostensivo é quem pratica atos perante terceiros e quem aparece perante eles, dirigindo-se contra ele eventuais direitos, pretensões, ações e exceções. Por sua vez, o sócio participante não se relaciona externamente. Seu vínculo é interno e exclusivamente com o sócio ostensivo, o que impede, por consequência, que o sócio participante seja responsabilizado pelos negócios desenvolvidos pelo sócio ostensivo 
com terceiros, salvo se com eles interagir e contratar, hipótese em que sua responsabilidade se torna solidária (art. 993, parágrafo único, do Código Civil de 2002).

Demonstrou-se, no que diz respeito à sua contribuição, que os sócios da SCP podem prover em prol da conta de participação dinheiro, bens ou somente trabalho. Tipicamente, o sócio participante provê recursos financeiros ou bens ao sócio ostensivo para viabilizar a consecução do empreendimento. No entanto, permite-se que ele contribua com serviços. Mas, se o fizer, o sócio participante não poderá se obrigar junto a terceiros, sob pena de responder solidariamente com o sócio ostensivo (art. 993, parágrafo único, do Código Civil). Além disso, eventual engajamento desse figurante com terceiros, em qualquer caso, somente poderá ocorrer em caráter excepcional, porque a abstenção do sócio participante constitui um dos elementos da causa jurídica da SCP.

Também no Capítulo 3, foi demonstrado que há liberdade para as partes estabelecerem os critérios de repartição dos lucros que lhes aprouverem, sendo mister, em qualquer caso, que os sócios partilhem não só os ganhos, como também as perdas, sob pena de desvirtuamento da sociedade. É que, não fosse assim, o negócio jurídico entre sócios ostensivo e participante poderia ser qualificado como mera prestação de serviço ou como um contrato de trabalho, por exemplo, se a contribuição do sócio participante consistisse em serviços, modificando o regime tributário dos rendimentos auferidos pelo aludido sócio na SCP, conforme esclarecido no Capítulo 6.

A SCP não detém nome empresarial. O nome empresarial, a denominação ou mesmo a mera designação, são próprios de entes dotados de publicidade, é dizer, entes para os quais a lei impõe registro e, pois, publicidade, sejam eles providos ou não de personalidade jurídica. A SCP não se sujeita a tal obrigação por ser interna e ineficaz perante terceiros e, pois, por não ter a publicidade como um de seus elementos característicos.

A despeito disso, em decorrência da equiparação da SCP à pessoa jurídica para fins tributários, a RFB determina a indicação nome empresarial ou nome fantasia quando da inscrição da SCP no CNPJ. A norma da RFB não impõe à SCP, ou a seus sócios, a atribuição de nome empresarial ou nome fantasia à sociedade. Basta que seja declarada a existência da SCP, qualquer que seja a designação que se lhe atribua para fins cadastrais, de forma a permitir à RFB identificar a sociedade, viabilizando, afinal, que os resultados da SCP sejam retratados separadamente daqueles próprios do sócio ostensivo, obtidos fora do empreendimento da SCP. Se o tiver, o sócio ostensivo - que exerce externamente a atividade da SCP - pode indicar seu nome empresarial para efeito de cadastramento da 
SCP no CNPJ, podendo ainda mencionar, no campo relativo ao nome fantasia, a existência da SCP.

Como mencionado no Capítulo 3, a ausência de nome empresarial não impede que os sócios adotem uma designação para a SCP - a qual será interna do ponto de vista de sua eficácia. Isto, aliás, já acontecia - antes mesmo da determinação de inscrição da SCP no CNPJ - para atender a exigências da RFB relativas à escrituração comercial. De fato, em decorrência da determinação da RFB de que haja escrituração destacada ou separada das operações e resultados da SCP, essa sociedade já dispunha de designação interna, voltada a permitir que a apuração dos tributos referentes à SCP fosse feita separadamente, isto é, independentemente da tributação do sócio ostensivo, ainda que em nome dele.

O uso de designação interna na escrituração do sócio ostensivo, determinada pela RFB, não acarreta, de per si, sua exteriorização, tampouco seu desvirtuamento. Pelo contrário. Independentemente da obrigação de índole tributária, a adoção de designação na escrituração comercial, que individualize a SCP e seus sócios, sempre foi recomendada com vistas a evitar sua confusão com a sociedade em comum.

A SCP também não tem sede ou endereço. A sede ou o endereço definem o domicílio onde se podem exercitar e cumprir os direitos e obrigações deles resultantes (art. 78 do Código Civil). Trata-se de atributos característicos de entes que podem contratar ou ser contratados, demandar ou ser demandados, ainda que não detenham personalidade jurídica, isto é, atributos de entes que ostentam capacidade negocial e processual, o que não acontece na SCP. Embora a RFB, para efeito de inscrição da SCP no CNPJ, determine a indicação de endereço, isso se dá sem qualquer transgressão ou desvirtuamento do tipo societário, pois, sendo a SCP desprovida de endereço, deve ser indicado o domicílio ou a sede do sócio ostensivo, afinal é ele quem pode contratar e ser contratado, demandar e ser demandado.

Como se viu no Capítulo 3, não há formalidades necessárias à constituição da SCP. Tanto no regime do Código Comercial de 1850, como naquele do Código Civil de 2002, a simplicidade sempre foi nota característica da SCP. Por decorrência dessa informalidade, a prova do pacto firmado entre as partes pode ser feita por qualquer meio lícito. Não se exigindo forma especial para sua celebração, admite-se, até mesmo, que a SCP seja constituída verbalmente. A despeito disto, a legislação tributária obriga que o sócio ostensivo apresente à RFB documento comprobatório da existência da SCP. Este fato, se não obsta sua constituição verbal, ao menos impõe maior formalidade à SCP, diminuindo sua simplicidade, sendo insuficiente, contudo, para atribuir-lhe complexidade. 
No tocante à sua relação com terceiros, demonstrou-se no Capítulo 3 que a SCP é ineficaz. De fato, se internamente a SCP constitui um contrato de sociedade de caráter plurilateral, associativo, de cooperação ou colaboração, externamente ela é ineficaz. No plano externo, quem se apresenta é o sócio ostensivo, de tal sorte que a natureza das relações por ele travadas com terceiras dependerá das características do respectivo negócio jurídico, podendo, assim, a título ilustrativo, ser um contrato bilateral de compra e venda, ou um contrato unilateral de doação.

No entanto, o fato de a SCP não integrar, juridicamente, relações com terceiros não significa que ela - ou que os resultados dela provenientes - seja oculta do ponto de vista tributário. Não obstante a SCP não se relacione com terceiros, os resultados do empreendimento estão submetidos à tributação, devendo, de conseguinte, ser informados às autoridades fiscais - o que já acontecia antes de sua equiparação à pessoa jurídica, promovida pelo art. $7^{\circ}$ do Decreto-lei n. 2303/86.

No Capítulo 3, esclareceu-se que não há capital social na SCP porque o patrimônio empregado pelo sócio ostensivo na consecução do objeto constitutivo do empreendimento não pertence à sociedade; porque a sociedade é interna, não operando efeitos externamente, pelo que, se lhe fosse atribuído capital, a estipulação teria validade somente entre os sócios, não servindo a correspondente cifra de garantia, ainda que indireta, a credores, dada a ineficácia desse tipo societário em relação a terceiros; e porque, sendo interna e funcionando somente entre seus sócios, a sociedade não emite quotas ou ações.

Não obstante a SCP não disponha de capital social, o item 6.1 da Instrução Normativa SRF n. 179, de 30.12.1987, estabelece que os valores entregues pelos sócios constituem o capital da SCP, o qual deverá ser registrado em conta representativa do patrimônio líquido da SCP. A norma tributária decorre da equiparação da SCP à pessoa jurídica para efeito de apuração de IRPJ, CSL, contribuição ao PIS e COFINS, não tendo o condão de desvirtuar o instituto.

Do ponto de vista tributário, a determinação de que seja indicado capital social deve ser entendida como medida de controle, que viabiliza a aplicação da legislação tributária e que igualmente viabiliza, quando necessário e quando couber, a avaliação de eventual investimento feito pelo sócio participante no empreendimento pelo MEP. Para atender à norma tributária, o capital social da SCP será o resultado da avaliação monetária das contribuições de cada sócio. Mas, se um ou mais sócios não aportarem bens ou recursos, e sim serviços ou expertise para a consecução no empreendimento, ter-se-á que 
atribuir ao capital social um valor simbólico para fins de cumprimento da legislação tributária.

A norma tributária que cuida do capital social, como dito, não desvirtua a SCP. A maleabilidade do instituto e de seu regime jurídico permite, independentemente do que dispõe a norma tributária, que as partes convencionem o capital da sociedade e sua participação nesse capital, dividindo-o em quotas, se o desejarem.

Por fim, demonstramos no Capítulo 3 que os bens e direitos empregados pelos sócios para o desenvolvimento da atividade constitutiva do objeto social não pertencem à SCP. Na verdade, eles pertencem a um, a alguns ou a todos os sócios. Tanto é assim que o parágrafo $1^{\circ}$ do art. 994 do Código Civil dispõe que a especialização patrimonial somente produz efeitos em relação aos sócios.

Assim, os bens que compõem o patrimônio especial da SCP tanto podem pertencer exclusivamente ao sócio ostensivo, como pertencer conjuntamente a este e ao sócio participante, ou somente ao sócio participante, podendo este ceder somente a posse dos bens àquele, conforme disposto em contrato ou em lei. Para efeito de definição da titularidade dos bens empregados no desenvolvimento da SCP, deve-se analisar o quanto contratado entre os sócios, bem assim as normas que disciplinam a constituição ou a transferência da propriedade, da posse, do uso ou de outros direitos reais.

A constatação de que a SCP não dispõe de autonomia patrimonial contribui para a demonstração de que os resultados e operações da sociedade devem ser retratados, do ponto de vista da Ciência Contábil, na escrituração comercial do sócio ostensivo, e não de forma apartada e segregada, em escrituração própria da SCP. A despeito disso, a legislação tributária impõe que se faça tal separação, mantendo-se livros próprios da $\mathrm{SCP}$, distintos dos livros do sócio ostensivo, de modo a contribuir para a fiscalização, conforme demonstrado no Capítulo 5.

Após analisarmos a natureza e causa jurídica da SCP, bem como suas características essenciais, apresentamos no Capítulo 4 as diversas formas de relacionamento entre o Direito Tributário e o Direito Privado, demonstrando que o legislador tributário pode promover: (1) remissão; (2) remissão com ajustes; (3) independência; e (4) interferência reversa.

Na hipótese de remissão, o Direito Tributário adota conceitos de Direito Privado sem deles divergir, nem do ponto de vista conceitual, nem quanto aos respectivos efeitos. 
O legislador tributário também pode ser independente, o que se verifica quando a obrigação tributária dependa ou remeta a fato ou instituto não disciplinado no Direito Privado.

Ainda, o Direito Tributário pode exercer domínio sobre o Direito Privado. É que, ressalvadas as situações abrangidas pelo art. 110 do CTN, o legislador tributário tem autorização para criar conceitos próprios e inexistentes no Direito Privado, ocasionando a recepção de elementos tributários pelo Direito Privado, bem como tem autorização para, em alguns casos, alterar o Direito Privado.

Por fim, na remissão com ajustes, o legislador tributário remete a institutos de Direito Privado, atribuindo-lhes, no entanto, efeitos diversos, como autoriza o art. 109 do CTN.

De acordo com o art. 109 do CTN, o legislador tributário pode, em determinadas circunstâncias, atribuir efeitos próprios a institutos de Direito Privado, a demonstrar que o Direito Tributário não está sempre jungido, submetido ou vinculado aos ditames do Direito Privado. Mas, ao fazê-lo, o legislador tributário não tem permissão para invadir a seara do Direito Privado, revogando ou modificando os conceitos e regimes jurídicos de institutos disciplinados em tal ramo. Ao legislador é dado, apenas, atribuir efeitos tributários próprios a determinados institutos, distintos daqueles que ordinariamente adviriam da correspondente disciplina do Direito Privado, sem que isso implique desfiguração desses institutos.

O legislador optou pela remissão com ajustes ao tratar da SCP. De fato, o legislador tributário, na esfera federal, mais precisamente em matéria de IRPJ, CSL, contribuição ao PIS e COFINS, louvando-se da autorização dada pelo art. 109 do CTN, atribuiu efeitos tributários distintos a tais entidades, quando comparados à disciplina a elas conferida pelo Direito Privado, equiparando-as à pessoa jurídica. A validade e os efeitos dessa equiparação foram examinados no Capítulo 5.

No Capítulo 5, analisamos as normas tributárias que disciplinaram a SCP no âmbito do imposto de renda.

Demonstramos que o Decreto-lei n. 1134/70 instituiu incentivos fiscais concedidos a empreendimentos florestais, inclusive àqueles desenvolvidos mediante SCP. De acordo com o art. $1^{\circ}$ do Decreto-lei n. 1134/70, a partir do exercício financeiro de 1971, as pessoas jurídicas poderiam descontar até $50 \%$ do valor do imposto de renda devido na declaração de rendimentos para a aplicação em empreendimentos florestais, cujos projetos tivessem sido aprovados pelo Instituto Brasileiro de Desenvolvimento Florestal. O 
parágrafo $1^{\circ}$ do mesmo dispositivo acrescentava que as importâncias descontadas poderiam ser aplicadas em projetos de desenvolvimento florestal sob a forma de participação societária acionária ou de participação societária não acionária em projetos de "pluriparticipação".

Na regulamentação do incentivo previsto no Decreto-lei n. 1134/70, o Decreto n. 68565, de 29.4.1971, previu em seu art. 16 que as chamadas sociedades não acionárias de pluriparticipação, referidas pelo art. 1º, parágrafo $1^{\circ}$, inciso II, do Decreto-lei n. 1134/70, eram equiparadas às SCP, regidas, à época, pelos art. 325 a 328 do Código Comercial. O sócio ostensivo seria responsável pelo empreendimento florestal, cabendo-lhe emitir "Certificado de Participação em Reflorestamento" correspondente à quantia investida pelos aplicadores dos incentivos fiscais (art. 16, parágrafo $2^{\circ}$, e art. 17). Os sócios participantes, por sua vez, eram os depositantes que aplicavam a dedução de seu imposto de renda em empreendimentos florestais constituídos sob a forma de SCP (art. 16, parágrafo $1^{\circ}$ ).

O uso crescente da SCP - desencadeado pela concessão de incentivos fiscais como aqueles concedidos em matéria florestal - contribuiu para que fossem editadas normas disciplinando os aspectos tributários relativos a esse tipo societário.

A primeira dessas normas foi o Parecer Normativo CST n. 345/71, que vigorou até 31.12.1986 e que dispunha sobre a forma de apuração e tributação dos rendimentos oriundos de SCP.

Ao tempo em que editado o Parecer Normativo CST n. 345/71, a SCP não era contribuinte do imposto de renda distinto de seus sócios (ostensivo e participante). A SCP não tinha seu próprio lucro tributável; os lucros ou rendimentos eram de cada sócio. Assim, os rendimentos oriundos da sociedade eram tributados em parte como rendimentos do sócio ostensivo, em parte como rendimentos do sócio participante.

Na vigência do Parecer Normativo CST n. 345/71, o tratamento tributário aplicável aos resultados da SCP era equivalente à disciplina que lhe foi atribuída pelo Direito Privado, na medida em que, tanto para o Direito Privado como para o Direito Tributário, a SCP era uma sociedade desprovida de personalidade jurídica, não equiparada à pessoa jurídica, não tendo a legislação tributária atribuído nenhum efeito distinto ao tipo societário, se comparado à sua disciplina e aos efeitos oriundos do Direito Privado, a despeito da autorização concedida pelo art. 109 do CTN.

Em matéria tributária, os sujeitos passivos do imposto de renda eram o sócio ostensivo e o sócio participante, nos termos e para os efeitos do art. 121, parágrafo único, inciso I, do CTN, os quais manifestavam capacidade contributiva, auferindo renda e 
proventos oriundos do empreendimento constitutivo da $\mathrm{SCP}$, sujeitos à tributação em conformidade com o regime tributário aplicável a cada um de tais sócios. Logo, os sócios ostensivo e participante - pessoas físicas submetiam-se à legislação do IRPF, enquanto os sócios pessoas jurídicas ou os sócios pessoas físicas equiparados pela legislação do imposto de renda à pessoa jurídica - ostensivo e participante - sujeitavam-se à legislação do IRPJ.

Esse regime foi modificado com a edição do Decreto-lei n. 2303, de 21.11.1986, o qual equiparou a SCP, para fins de imposto de renda, à pessoa jurídica (art. $7^{\circ}$ ). Com isso, a partir de $1^{\circ} .1 .1987$, os resultados da SCP passaram a ser tributados como se ela fosse uma pessoa jurídica, isto é, como se fosse uma sociedade personificada, sem sua junção com os demais resultados do sócio ostensivo, auferidos fora do empreendimento objeto da SCP, ou do sócio participante.

No que atine à sujeição passiva, a equiparação promovida pelo art. $7^{\circ}$ do Decretolei n. 2303/86 não se distancia do regime anterior à sua edição, disciplinado pelo Parecer Normativo CST n. 345/71. A SCP não passou a ser contribuinte do imposto de renda distinto de seus sócios (ostensivo e participante), mesmo após a equiparação, como já não o era na vigência da legislação anterior, regulamentada pelo Parecer Normativo CST n. $345 / 71$.

Mas, por força da equiparação, a tributação da totalidade dos resultados da SCP pelo imposto de renda deve ocorrer, em um primeiro momento, no nível da sociedade (ou do sócio ostensivo, porque ele empreende a atividade da SCP). Em um segundo momento, tributa-se a renda no nível do sócio participante, quando da distribuição dos lucros que lhe forem atribuíveis.

Diferencia-se - esse formato de tributação - do regime disciplinado pelo Parecer Normativo CST n. 345/71, porque, neste, os rendimentos oriundos da sociedade eram tributados em parte como rendimentos do sócio ostensivo, em parte como rendimentos do sócio participante.

A tributação da renda no nível da sociedade, ocorrida após a equiparação da SCP à pessoa jurídica, significa tributar o próprio sócio ostensivo, sendo sua a capacidade contributiva alcançada pelas normas tributárias, nos termos e para os efeitos do art. 121, parágrafo único, inciso I, do CTN, o que é compatível com a lei civil, uma vez que a atividade constitutiva do objeto social da SCP, reveladora da capacidade contributiva e geradora de resultados passíveis de tributação, é exercida unicamente por ele (art. 991, caput, do Código Civil). 
O sócio participante também é contribuinte, mas contribuinte do imposto de renda incidente sobre os rendimentos que lhe competem em função de sua participação na SCP, os quais lhe são distribuídos na forma lucro. Quer dizer, a capacidade contributiva do sócio participante manifesta-se nos limites dos lucros que lhe são distribuídos, não alcançando os resultados apurados diretamente pelo sócio ostensivo no desempenho da atividade da SCP. Quem aufere esses resultados é o sócio ostensivo, sendo sua a capacidade contributiva. Daí dizer-se que ele é o contribuinte do imposto de renda que incide sobre os resultados apurados no desenvolvimento do objeto social da SCP.

Veja-se que a lei tributária está em sintonia com a disciplina contida na lei civil, porquanto, tanto para uma como para outra, a responsabilidade é exclusiva do sócio ostensivo. É do sócio ostensivo a obrigação de apurar os resultados da SCP e recolher os tributos devidos sobre os mesmos resultados. O sócio participante não responde com o sócio ostensivo pelas obrigações tributárias incidentes sobre os resultados decorrentes do empreendimento da SCP.

As afirmações precedentes acerca da sujeição passiva de cada sócio da SCP permitem-nos concluir que não há, entre eles, solidariedade, o que já ocorria antes da equiparação. Diz-se não haver solidariedade, porque cada sócio manifesta capacidade contributiva nos limites da renda que lhe compete. Os sócios têm, nesses termos, relação pessoal e direta com a situação que constitui o fato gerador do imposto de renda, o que os coloca, individual e separadamente, na condição de contribuintes do imposto, na forma do art. 121, parágrafo único, inciso I, do CTN, sem solidariedade, já que cada um responde pelo tributo calculado sobre a parcela do acréscimo patrimonial oriundo da SCP que lhe cabe na forma do contrato e da lei tributária.

Também não há solidariedade entre os sócios ostensivo e participante lastreada no art. 124, inciso I, do CTN. De acordo com o referido dispositivo, há solidariedade quando as pessoas tenham interesse comum na situação que constitui o fato gerador da obrigação principal. O interesse comum, a que se refere o art. 124, é de cunho jurídico, constatandose quando duas ou mais pessoas ocupam a mesma posição da situação fática que dá lugar ao nascimento da obrigação tributária.

Os sócios ostensivo e participante não praticam atos ou negócios jurídicos conjuntamente. Isso não é característico da SCP. Os sócios ostensivo e participante, nesse contexto, não auferem renda ou receita em comum. Sendo assim, por não figurarem no mesmo polo da relação que dará azo ao nascimento da obrigação tributária, não há solidariedade entre eles por inexistir interesse comum. 
Por outro lado, se houver mais de um sócio ostensivo em uma mesma SCP, buscando, todos eles, cumprir o mesmo objeto, por força da equiparação, e somente por força dela, eles serão solidários pelo adimplemento da obrigação tributária resultante dos negócios empreendidos mediante SCP, porque existirá, nessa situação, interesse comum na situação que constitui o fato gerador da obrigação tributária, nos termos e para os efeitos do art. 124, inciso I, do CTN. Com efeito, existirá, na hipótese, renda ou receita adquirida em comum, componente da mesma unidade econômica autônoma cujos resultados e operações são suscetíveis de tributação pelo imposto de renda.

A equiparação determinada pela legislação tributária encontra justificativa no interesse da arrecadação tributária. É que a informalidade característica da SCP trazia óbices à administração tributária no tocante à verificação do correto recolhimento de tributos. Com a equiparação determinada pelo Decreto-lei n. 2303, a informalidade da SCP não desapareceu, já que o arquivamento de ato constitutivo da sociedade perante o órgão de registro de empresas mercantis, ou perante qualquer outro registro público, continua prescindível. Mas, com a equiparação, a legislação tributária reforçou que a sociedade não pode ficar oculta aos olhos do fisco, embora o possa em relação aos demais.

A equiparação promovida pelo art. $7^{\circ}$ do Decreto-lei n. 2303 encontra amparo no ordenamento jurídico, mais precisamente nos art. 109, 110, 116, inciso I, e 126 do CTN, tendo ocorrido para evitar que informações sobre empreendimentos objeto de SCP e sobre seus resultados fossem escamoteadas do fisco ou simplesmente não chegassem ao seu conhecimento. Não obstante a equiparação, a sociedade não se tornou sujeito passivo tributário. Trata-se de mero critério de quantificação, que aparta os resultados do empreendimento da SCP dos demais resultados obtidos pelo sócio ostensivo fora da referida sociedade. Sendo a equiparação um critério de quantificação de determinados tributos incidentes sobre o resultado do empreendimento desenvolvido por meio de SCP, é desinfluente o debate em torno da natureza jurídica da SCP. A tributação da SCP, como se pessoa jurídica fosse, apenas obsta a que lucros, perdas, receitas, despesas, créditos e prejuízos do sócio ostensivo se comuniquem com aqueles próprios da SCP.

No Capítulo 5, demonstrou-se que, na regulamentação art. $7^{\circ}$ do Decreto-lei n. 2303, a legislação tributária não distorceu o instituto da SCP, comprometendo a definição, o alcance e os efeitos privados decorrentes das normas do Código Civil aplicáveis a tal tipo societário, ao criar dezenas de deveres instrumentais.

Um desses deveres é a inscrição da SCP no CNPJ. Trata-se de medida criada no interesse da arrecadação e da fiscalização de tributos, nos termos do art. 113 do CTN, na 
medida em que permite o aprimoramento dos controles do fisco sobre os resultados da SCP, sobre as obrigações tributárias que lhe devem ser impostas e sobre o cumprimento da legislação fiscal.

A inscrição da SCP no CNPJ não desvirtua o instituto, porquanto suas características essenciais, ditadas pelo Direito Privado, e que identificam sua causa jurídica, analisadas nos Capítulos 2 e 3, continuam preservadas.

O dever de inscrição no CNPJ, embora diminua a discrição e a informalidade da SCP, não desencoraja o uso do instituto, uma vez que a sociedade é visível, em caráter obrigatório, apenas aos olhos do fisco, podendo permanecer oculta em relação a terceiros, inclusive sem arquivamento de seus atos em registro que lhes confira ampla publicidade, caso os sócios assim desejem.

As normas editadas pela RFB não requerem a identificação do sócio participante no cadastro do CNPJ. A despeito de não haver informação acerca da identidade do sócio participante no comprovante de inscrição no CNPJ divulgado publicamente, a RFB tem conhecimento desse figurante porque recebe do sócio ostensivo documentos que identificam a sociedade e seus sócios, como condição necessária à inscrição da SCP no CNPJ, como também porque recebe informações do sócio ostensivo e do sócio participante - em declarações e escriturações - sobre a participação deste nos resultados do empreendimento. De fato, é dever do sócio ostensivo apontar, destacadamente, os resultados da SCP e a parte dos lucros ou perdas atribuíveis ao sócio participante, assim como é dever do último declarar os resultados provenientes da SCP que lhe caibam. Daí porque sua identidade é de conhecimento da RFB, não decorrendo da determinação de inscrição da sociedade no CNPJ.

$O$ fato de a RFB ter conhecimento da identidade do sócio participante não significa dizer que terceiros, por decorrência, também o tenham. É que os documentos e as informações confiados à RFB não podem ser divulgados, estando protegidos por sigilo, nos termos do art. 198 do CTN.

A despeito de a inscrição no CNPJ não conflitar com a natureza, nem desencorajar o uso desse tipo societário, a rigor, ela carrega o inconveniente de aumentar os deveres instrumentais que o sócio ostensivo deve cumprir (escriturações e declarações) e, pois, de aumentar os chamados custos de conformidade a que ele se submete. Dentre esses deveres, mencione-se a obrigação de apresentar escrituração comercial e fiscal da SCP separada daquela do sócio ostensivo. 
Sobre o tema da escrituração dos resultados e operações da SCP, demonstrou-se no Capítulo 5 que, do ponto de vista da Ciência Contábil, a SCP não constitui uma entidade, dado não possuir autonomia patrimonial. Disto resulta não haver obrigatoriedade de manutenção de escrituração comercial separada e apartada para a SCP, diversa dos assentamentos contábeis do sócio ostensivo. A falta de autonomia patrimonial da SCP, na verdade, impõe que seus resultados e operações sejam retratados na própria escrituração comercial do sócio ostensivo, atendendo, assim, ao objetivo da Ciência Contábil de exprimir, de forma útil e relevante, a situação patrimonial do sócio ostensivo.

Muito embora para a Contabilidade as operações praticadas em SCP devam ser registradas nas demonstrações contábeis do próprio sócio ostensivo, na medida em que compõem seu patrimônio, não podendo, pois, ser omitidas ou excluídas de sua escrituração comercial, sob pena de o retrato patrimonial do sócio ostensivo não ser fidedigno, por outro lado, em cumprimento à disposição contida no art. 269 do RIR/18 e às normas editadas pela RFB, o sócio ostensivo dever manter livros comerciais obrigatórios (Diário, Razão e seus auxiliares) que atestem, separadamente, as operações e os resultados decorrentes da SCP, o mesmo aplicando-se a livros e declarações fiscais.

A elaboração de livros próprios da SCP, referida no art. 269 do RIR/18, enquanto obrigação tributária acessória, deve ser cumprida paralelamente e sem prejuízo das normas contábeis a que se sujeita o sócio ostensivo. Em razão disso, para atender às normas contábeis, societárias e tributárias, é possível que o sócio ostensivo tenha que duplicar alguns de seus registros contábeis, retratando as operações da SCP em seus livros comerciais e também em livros comerciais da SCP. Essa duplicação, embora ocorra em benefício da administração tributária, pode ocasionar aumento dos custos operacionais e de conformidade a que muitas empresas se sujeitam.

A criação de diversos deveres instrumentais não pode ser excessiva, nem desnecessária, impondo-se sua adequação à finalidade a que se presta, além de dever obediência à equidade em cada situação concreta, sem prejuízo de ser coerente e congruente com as situações que alcançam, sob pena de ferir a proporcionalidade e a razoabilidade.

A criação de dezenas de deveres instrumentais a serem cumpridos pelo sócio ostensivo em nome da SCP pode encarecer e desestimular uso do instituto. Mais do que isso, tal exigência pode atentar contra a proporcionalidade e a razoabilidade se for detectado excesso, ou se for constatado que o fisco já tinha à sua disposição as informações que solicita por meio de outras declarações ou escriturações (exame da proporcionalidade), 
ou se causar iniquidade, desencorajando o uso do instituto para contribuintes que estejam em situação equivalente, criando generalizações indevidas ou, ainda, estabelecendo incongruências e incoerências entre as medidas adotadas e a realidade negocial e as normas que a disciplinam (exame da razoabilidade).

A despeito do possível aumento dos custos de conformidade a que se submete o sócio ostensivo, não há ofensa à proporcionalidade e à razoabilidade, porque os deveres instrumentais impostos a ele viabilizam a fiscalização tributária, que era dificultada pelos lançamentos dos resultados da SCP em conta especial em sua própria escrituração comercial.

A despeito de indesejados, os elevados custos de conformidade a que muitos sujeitos passivos se sujeitam nem sempre são ilegítimos, pois podem encontrar justificação no ordenamento jurídico, atendendo ao interesse da arrecadação ou da fiscalização, na forma do art. 113, parágrafo $2^{\circ}$, do CTN, como nos parece ocorrer no caso das SCP.

Por fim, no Capítulo 5, analisamos se os sócios da SCP devem avaliar seu investimento por alguma das metodologias previstas na lei societária (Lei n. 6404/76).

Viu-se que, não obstante a equiparação da SCP à pessoa jurídica, disso não decorre que seus sócios estejam - sempre - obrigados a adotar metodologias de avaliação de investimento. É que as metodologias de avaliação de investimento estão normatizadas pela legislação societária e contábil, e não pela lei tributária. Quando o legislador tributário adota tais metodologias, ele o faz mediante remissão sem ajustes, analisada no Capítulo 4.

Do ponto de vista societário e contábil, o sócio ostensivo não está sujeito à avaliação de investimento, uma vez que ele se confunde com a própria SCP. O sócio participante, por sua vez, pode ou não estar sujeito a uma das metodologias de avaliação de investimento; estando sujeito a tal avaliação, a metodologia a que se submeterá dependerá das circunstâncias ou características de seu investimento (para o MEP, art. 248, inciso II, da Lei n. 6404/76 e CPC 18; para o método do custo, art. 183, inciso III, da Lei n. 6404/76); já se o negócio for considerado como uma operação em conjunto, o MEP não será aplicável, devendo o sócio participante contabilizar sua parcela sobre o ativo operado em conjunto e sua parcela sobre os passivos, devendo também reconhecer sua parcela da produção, receitas e despesas, em conformidade com os critérios firmados no acordo contratual, conforme item B.18 do CPC 19.

No Capítulo 6, demonstramos, em detalhes, os efeitos decorrentes da equiparação da SCP à pessoa jurídica. Esclareceu-se que a equiparação da SCP à pessoa jurídica, fiscalmente, significa que ela é autônoma em relação a seu sócio ostensivo. 
$\mathrm{O}$ art. $7^{\circ}$ do Decreto-lei n. 2303/86 equiparou a SCP à pessoa jurídica para fins do imposto de renda. A equiparação alcança também a CSL, porque a lei que a institui e disciplina define seu contribuinte como a pessoa jurídica e as pessoas a ela equiparadas pela legislação do imposto de renda (art. $4^{\circ}$ da Lei n. 7689, de 15.12.1988).

A equiparação, conforme explicado no Capítulo 5, constitui critério de quantificação do imposto e da contribuição. A consequência desse critério de quantificação é que os resultados da SCP devem ser tributados separadamente por um dos possíveis regimes de tributação da renda aplicáveis às pessoas jurídicas, não se misturando com os resultados do sócio ostensivo, obtidos fora do empreendimento da SCP. Lucros, perdas, receitas, despesas, créditos e prejuízos oriundos da $\mathrm{SCP}$, portanto, não se misturam com lucros, perdas, receitas, despesas, créditos e prejuízos do sócio ostensivo apurados em outros negócios, que não naqueles relacionados à SCP.

Por decorrência da equiparação:

- A SCP, para efeito de apuração do IRPJ e da CSL, não se confunde com o sócio ostensivo, de modo que seus resultados não podem ser tributados diretamente neste.

- O resultado da SCP não pode compor o lucro do sócio ostensivo, nem para acrescê-lo, nem para diminuí-lo.

- Não se faz possível protelar a tributação dos resultados oriundos da SCP para o final da existência da sociedade, de tal sorte que, se suas atividades se projetarem por mais de um exercício, deverão ser realizadas tantas apurações de IRPJ e CSL quantas forem necessárias até o término de sua existência.

- O prejuízo fiscal e a base de cálculo negativa da CSL apurados pela SCP somente poderão ser compensados, respectivamente, com o lucro real e com o resultado ajustado positivo decorrente da mesma SCP, sendo vedada a compensação de prejuízo fiscal, base de cálculo negativa da CSL e lucros entre duas ou mais SCP ou entre estas e o sócio ostensivo (se uma mesma SCP for integrada por mais de um sócio ostensivo, o prejuízo fiscal e a base de cálculo negativa da CSL apurados na atividade desempenhada conjuntamente pelos sócios ostensivos poderão ser compensados, respectivamente, com o lucro real e o resultado ajustado da CSL da SCP, não devendo haver separação, para esses fins, entre os resultados - positivos e negativos - apurados por cada um dos sócios ostensivos).

- Indébitos de IRPJ e CSL da SCP não podem ser compensados com tributos administrados pela RFB devidos pelo sócio ostensivo fora do empreendimento objeto da SCP, e vice-versa; ainda, as retenções desses tributos, feitas em caráter de antecipação, 
quando relacionados à SCP, somente podem ser objeto de dedução e compensação relativamente a tributos devidos pela $\mathrm{SCP}$; já em relação às retenções vinculadas a operações próprias do sócio ostensivo, sua dedução e sua compensação somente podem ser realizadas com tributos do sócio ostensivo, apurados fora do empreendimento constitutivo da SCP.

- Incentivo fiscal auferido por uma SCP não se estende ao sócio ostensivo, e viceversa.

- O regime de apuração da renda e dos proventos de qualquer natureza a que se submete o sócio ostensivo, seja de aplicação obrigatória, seja optativo, não interfere no regime aplicável para a SCP, podendo a última ser tributada pelo lucro presumido e aquele pelo lucro real, e vice-versa, ou um deles ser tributado pelo lucro real anual e o outro pelo lucro real trimestral, por exemplo; com a equiparação, abre-se a possibilidade de utilização de qualquer regime de apuração do lucro aplicável às pessoas jurídicas para efeito de cálculo do IRPJ e da CSL devidos sobre os resultados da SCP. Exceção será feita somente se, por força das circunstâncias de cada caso concreto, a lei impuser a adoção de determinado regime de tributação, ou impedir a adoção de determinado regime optativo.

- Não obstante a SCP seja desprovida de capital social, em decorrência da equiparação, aplica-se à referida sociedade e a seus sócios o disposto no art. 22 da Lei n. 9249, de 26.12.1995, segundo o qual os bens e direitos do ativo da pessoa jurídica que forem entregues a seus sócios a título de devolução de sua participação no capital social poderão ser avaliados pelo valor contábil ou de mercado. Se a devolução se realizar pelo valor de mercado, a diferença entre este e o valor contábil dos bens ou direitos será considerada ganho de capital, passível de tributação pelo IRPJ e pela CSL na pessoa jurídica que devolver bens e direitos a seus sócios. Já se a devolução ocorrer pelo valor contábil, é dizer, pelo custo histórico do bem ou direito entregue, a operação será neutra fiscalmente. Assim, na devolução de bens e direitos ao sócio participante, que integrem o patrimônio do sócio ostensivo destinado ao desenvolvimento da atividade da SCP, devem ser observadas as normas do art. 22 da Lei n. 9249/95. Essas normas aplicam-se, inclusive, por ocasião da liquidação da SCP, efetuada mediante prestação de contas, na forma do art. 996 do Código Civil.

- Os rendimentos vinculados ao empreendimento constitutivo da SCP são distribuídos aos sócios, isto é, são pagos ou creditados em favor do sócio participante e retidos em favor do sócio ostensivo, sob a forma de lucros (item 8 da Instrução Normativa SRF n. 179, de 30.12.1987), os quais são isentos do imposto de renda e da CSL, nos 


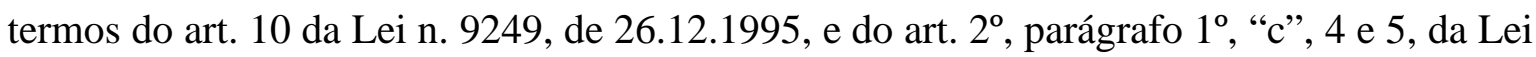
n. 7689, de 15.12.1988. Havendo lucro a distribuir, retratado na escrituração comercial, e ocorrendo sua distribuição em conformidade com o ajuste estabelecido entre os sócios da SCP, qualquer que seja esse ajuste, dada a liberdade das partes na pactuação relativa à partilha de resultados da sociedade, os valores pagos ao sócio participante, assim como os valores que o sócio ostensivo retiver para si, estarão isentos do imposto de renda, assim como estarão isentos, no caso de sócio pessoa jurídica, da CSL.

- Os sócios da SCP podem ser remunerados mediante pagamento ou crédito de JCP, dado que o JCP remunera não somente o capital investido, mas também a indisponibilidade dos lucros, bem como porque o pagamento ou crédito do JCP pressupõe a existência de lucros e patrimônio líquido, tudo o que existe e é compatível com a SCP, em virtude de sua equiparação à pessoa jurídica, por força da qual o sócio ostensivo deve elaborar balanço da sociedade, indicando, dentre outras grandezas, seu resultado e seu patrimônio líquido. Os correspondentes valores são dedutíveis da apuração do IRPJ e da CSL, no caso de SCP sujeita ao lucro real, observados os limites fixados no art. $9^{\circ}$ da Lei n. 9249.

- E é necessário verificar se, em determinadas transações, os sócios da SCP ou a própria SCP enquadram-se no conceito de partes ligadas ou vinculadas para efeito de aplicação de normas especiais antiabuso, como as regras de controle de preços de transferência (art. 18 a 24-B da Lei n. 9430, de 27.12.1996), as regras de subcapitalização (art. 24 e 25 da Lei n. 12249, de 11.06.2010) e as regras de distribuição disfarçada de lucros (art. 60 a 62 do Decreto-lei n. 1598, de 26.12.1977). Constatado que o ajuste foi celebrado entre partes vinculadas ou ligadas, a princípio o contribuinte deverá realizar os ajustes determinados pela legislação tributária.

No Capítulo 6, demonstrou-se também que a equiparação da SCP à pessoa jurídica é extensível à contribuição ao PIS (art. $1^{\circ}$, parágrafo $1^{\circ}$, da Lei Complementar 7/70) e à COFINS (art. $1^{\circ}$ da Lei Complementar n. 70/91) devidas no regime cumulativo, porque a legislação dessas contribuições sociais define seus contribuintes como a pessoa jurídica e as pessoas a ela equiparadas pela legislação do imposto de renda.

O mesmo não pode ser dito em relação à contribuição ao PIS e à COFINS devidas no regime não cumulativo de sua incidência. Isso porque as Leis n. 10637, de 30.12.2002, e 10833, de 29.12.2003, que dispõem, respectivamente, sobre a contribuição ao PIS e a COFINS não cumulativas, instituíram regramento inteiramente novo a respeito da incidência dessas contribuições sociais, tratando de todos os aspectos de sua hipótese de 
incidência tributária, sendo certo que, ao cuidar do aspecto pessoal do fato gerador dos referidos tributos, o art. $1^{\circ}$ de ambas as leis estabeleceu que o contribuinte é a pessoa jurídica que aufere receitas, sem remissão a qualquer outro dispositivo legal e sem referência à adoção do conceito de contribuinte da legislação do IRPJ. Corroborando essa afirmação, o art. $4^{\circ}$ da Lei n. 10637 e o art. $5^{\circ}$ da Lei n. 10833 dispõem, respectivamente, que o contribuinte da contribuição ao PIS e da COFINS é a pessoa jurídica que auferir as receitas a que se refere o art. $1^{\circ}$ das mesmas leis.

Diferentemente do que ocorre no regime cumulativo da contribuição ao PIS e da COFINS, no regime não cumulativo de sua incidência, não há norma determinando que a definição de pessoa jurídica (contribuinte das contribuições sociais) seja colhida na legislação do imposto de renda.

Também não há no regime não cumulativo referência aos dispositivos contidos na legislação pretérita, especialmente no que se refere à Lei Complementar 7/70 e à Lei Complementar n. 70/91. Na verdade, as únicas normas que determinam, de forma expressa, a observância da legislação vigente são os art. $8^{\circ}$ da Lei n. 10637 e 10 da Lei n. 10833. Contudo, esses dispositivos o fazem, não para que tal legislação seja aplicável às contribuições sociais não cumulativas, mas, sim, para determinar que certas pessoas ou receitas fiquem sujeitas à legislação anterior, isto é, à legislação de regência da contribuição ao PIS e a COFINS cumulativos, a qual não é extensível à disciplina das contribuições sociais regidas pelas Leis n. 10637 e 10833.

Quer dizer, as Leis n. 10637 e 10833, ao instituírem a não cumulatividade, não fizeram remissão ao regramento contido em outras leis a propósito do regime cumulativo de incidência da contribuição ao PIS e da COFINS. As Leis n. 10637 e 10833 inauguraram regime novo, regulando por inteiro as contribuições sociais devidas na sistemática não cumulativa (base de cálculo, alíquota, sujeitos ativo e passivo, momento da ocorrência do fato gerador e prazo de vencimento), razão pela qual as disposições anteriores são inaplicáveis para esses tributos, embora permaneçam em vigor, em conformidade com o disposto no art. $2^{\circ}$, parágrafo $2^{\circ}$, da LINDB.

A equiparação da SCP à pessoa jurídica aplicável à contribuição ao PIS e à COFINS devidas no regime cumulativo, tanto quanto ocorre com o IRPJ e a CSL, constitui critério de quantificação das contribuições. A consequência desse critério de quantificação é que os resultados da SCP devem ser tributados pela contribuição ao PIS e pela COFINS o que não aconteceria se, inexistindo equiparação, o sócio ostensivo fosse pessoa física, por exemplo. Tal tributação deve ocorrer em separado, não se misturando com os demais 
resultados do sócio ostensivo, obtidos fora do empreendimento da SCP. Receitas, créditos e indébitos oriundos da SCP, portanto, não se misturam com receitas, créditos e indébitos do sócio ostensivo apurados em outros negócios, que não naqueles relacionados à SCP. Assim:

- As receitas decorrentes do desenvolvimento da atividade da SCP devem ser oferecidas à tributação pelo sócio ostensivo no regime aplicável às pessoas jurídicas, mesmo que ele seja pessoa física; se o sócio ostensivo for pessoa jurídica, a tributação daquelas receitas deve ocorrer em separado, não se somando às demais receitas por ele auferidas em outros negócios, distintos da SCP.

- Os indébitos tributários da contribuição ao PIS e da COFINS, bem como as retenções dessas contribuições, feitas em caráter de antecipação, quando relacionados à SCP, somente podem ser objeto de dedução e compensação relativamente a tributos devidos pela SCP; já se os indébitos e retenções estiverem vinculados a operações próprias do sócio ostensivo, sua dedução e compensação somente poderão ser realizadas com tributos do próprio sócio ostensivo, apurados fora do empreendimento constitutivo da SCP.

- A completa segregação dos resultados da SCP e dos resultados individuais de seus sócios, decorrente da equiparação, também acarreta a possibilidade de a SCP ser tributada por regimes alternativos de tributação da contribuição ao PIS e da COFINS, como o RET.

- E na apuração da contribuição ao PIS e da COFINS, o sócio ostensivo não pode excluir ou deduzir os valores devidos ao sócio participante (art. 81 do Decreto n. 4524, de 17.12.2002, e art. 117 da Instrução Normativa RFB n. 1911, de 11.10.2019).

Por outro lado, não havendo equiparação da SCP à pessoa jurídica no regime não cumulativo de incidência da contribuição ao PIS e da COFINS, as receitas auferidas em decorrência da consecução do objeto social da referida sociedade devem ser tributadas pelo sócio ostensivo - se pessoa jurídica - sem necessidade de sua segregação em relação às demais receitas auferidas fora da SCP, obedecendo-se, assim, ao regime de incidência dessas contribuições aplicável ao sócio ostensivo. Se o sócio ostensivo estiver submetido ao regime não cumulativo, os créditos apurados na forma dos art. $3^{\circ}$ das Leis n. 10637 e 10833 poderão ser por ele aproveitados também sem qualquer segregação em relação aos demais créditos apurados fora da SCP. Já se o sócio ostensivo não estiver sujeito à incidência da contribuição ao PIS e da COFINS, por exemplo, por ser pessoa física, não deverá haver qualquer recolhimento das referidas contribuições sociais. 
Por fim, quer no regime não cumulativo, quer no não cumulativo, os rendimentos vinculados ao empreendimento constitutivo da SCP são distribuídos aos sócios sob a forma de lucros, os quais são isentos da contribuição ao PIS e da COFINS, nos termos do art. $3^{\circ}$, parágrafo $2^{\circ}$, inciso II, da Lei n. 9718 , de 27.11.1998, e dos art. $1^{\circ}$, parágrafo $3^{\circ}$, inciso $\mathrm{V}$, “b”, das Leis n. 10637, de 30.12.2002, e 10833, de 29.12.2003.

A análise pormenorizada do regime de apuração do IRPJ, da CSL, da contribuição ao PIS e da COFINS incidentes sobre os resultados e as operações da SCP evidencia que a equiparação desse tipo societário à pessoa jurídica, conquanto atribua efeitos distintos à entidade se comparados àqueles disciplinados no Código Civil de 2002 e no Código Comercial de 1850, não tem o condão de desfigurar o instituto, tampouco de desencorajar o seu uso. Trata-se de mero critério de quantificação dos referidos tributos que preserva sua natureza e causa jurídica, bem como suas características essenciais.

Não obstante a aludida equiparação, a SCP segue sendo um tipo societário maleável, que se amolda a uma gama variadas de negócios. Em que pese a equiparação tenha diminuído sua simplicidade, a SCP, ainda assim, é um tipo societário menos formal relativamente aos demais, o que torna seu uso vantajoso. Outra vantagem é que, por meio da SCP, permite-se a preservação da identidade de seu sócio participante, se as partes o desejarem, embora tal ocultamento não componha a causa jurídica do instituto. $\mathrm{O}$ ocultamento apenas não é admitido em relação ao fisco, para quem os resultados da SCP, mesmo antes da equiparação, já se submetiam à tributação.

Logo, em que pese a equiparação acarrete o dever de obediência a uma série de obrigações tributárias acessórias, ela não desfigura a SCP, não sendo suficiente para retirar-lhe a simplicidade, a informalidade, a dinamicidade, a flexibilidade e a virtuosidade, decorrentes de seu regime jurídico ditado pelo Direito Privado, dado que, como dito, a despeito da equiparação, restam preservadas a natureza, a causa jurídica e as características essenciais do tipo societário, as quais asseguram sua maleabilidade e maior despojamento. 


\section{REFERÊNCIAS}

ABBAGNANO, Nicola. Dicionário de Filosofia. Tradução da $1^{a}$ edição de Alfredo Bosi; revisão da tradução por Ivone Castilho Benedetti. 6. ed. São Paulo: Martins Fontes, 2018.

ACETI JÚNIOR, Luiz Carlos; REIS, Maria Flávia Curtolo. Sociedade em conta de participação. Revista dos Tribunais, São Paulo, v. 794, p. 727-745, 2001.

AFFONSO, Ana Carolina Barbuio. A sociedade em conta de participação no direito brasileiro. 2014. 210 f. Dissertação (Mestrado em Direito Comercial) - Universidade de São Paulo, São Paulo, 2014.

ALMEIDA, Carlos Guimarães de. A virtuosidade da sociedade em conta de participação. Revista de Direito Mercantil, Industrial, Econômico e Financeiro, São Paulo, n. 8, p. 45-63, 1972.

ALMEIDA, José Gabriel Assis de. A sociedade em conta de participação. Rio de Janeiro: Forense, 1989.

ALVES, José Carlos Moreira. As Figuras Correlatas da Elisão Fiscal. Revista Fórum de Direito Tributário, Belo Horizonte, n. 1, p. 11-20, 2003.

Direito Romano. v. 1, 13. ed. Rio de Janeiro: Forense, 2001.

AMARO, Luciano. Direito Tributário Brasileiro. 22. ed. São Paulo: Saraiva, 2017. . PIS/COFINS e Juros sobre o Capital Próprio. Revista Dialética de Direito Tributário, São Paulo, n. 239, p. 97-106, 2015.

ANDRADE JÚNIOR, Luiz Carlos de. A simulação no Direito Civil. São Paulo: Malheiros, 2016.

ANDRADE, Fábio Martins de. Da sociedade em conta de participação. Revista de Direito Privado. São Paulo, v. 9, n. 33, p. 39-56, 2008.

ANDRADE, José Maria Arruda de. Interpretação da norma tributária. São Paulo: MP, 2006.

ANDRADE, Leonardo Aguirra de. Planejamento tributário. São Paulo: Quartier Latin, 2016.

ASCARELLI, Tullio. Imposto sobre a renda e sociedades comerciais. In: Ensáios e Pareceres. São Paulo: Saraiva, 1952. p. 289-302.

. Natureza do contrato de sociedade - A simulação nas sociedades por quotas.

Ensaios e Pareceres. São Paulo: Saraiva, p. 176-181, 1952.

Problemas das sociedades anônimas e direito comparado. Campinas:

Bookseller, 2001.

Sociedade em conta de participação e imposto de selo. Ensaios e Pareceres. São Paulo: Saraiva, p. 360-364, 1952. 
ATALIBA, Geraldo. ICM - Hipótese de incidência. Bens importados para uso próprio. In: . Estudos e pareceres de Direito Tributário. v. 1. São Paulo: Revista dos

Tribunais, 1978. p. 120-138.

1968.

. Sistema constitucional tributário brasileiro. São Paulo: Revista dos Tribunais,

ÁVILA, Humberto. Competências tributárias: um ensaio sobre a sua compatibilidade com as noções de tipo e conceito. São Paulo: Malheiros, 2018.

. Eficácia do Novo Código Civil na legislação tributária. In: GRUPENMACHER, Betina Treiger (Coord.). Direito Tributário e o Novo Código Civil. São Paulo: Quartier Latin, 2004. p. 63-79.

. Juros sobre capital próprio: natureza jurídica e enquadramento legal. In: PRETO, Raquel Elita Alves (Org.). Tributação Brasileira em Evolução: estudos em homenagem ao Professor Alcides Jorge Costa. São Paulo: IASP, 2015. p. 980-993.

. Sistema constitucional tributário. 5. ed. São Paulo: Saraiva, 2012.

. Teoria da igualdade tributária. 3. ed. São Paulo: Malheiros, 2015.

. Teoria da segurança jurídica. 4. ed. São Paulo: Malheiros, 2016.

Teoria dos Princípios - da definição à aplicação dos princípios jurídicos. 15. ed. São Paulo: Malheiros, 2014.

AZEVEDO, Antonio Carlos Junqueira de. Natureza jurídica do contrato de consórcio. Classificação dos atos jurídicos quanto ao número de partes e quanto aos efeitos. Os contratos relacionais. A boa-fé nos contratos relacionais. Contratos de duração. Alteração das circunstâncias e onerosidade excessiva. Sinalagma e resolução contratual. Resolução parcial do contrato. Função social do contrato. Revista dos Tribunais, São Paulo, v. 832, p. 115-137, 2005.

BALEEIRO, Aliomar. Direito Tributário Brasileiro. 13. ed. Atualizada por Misabel Abreu Machado Derzi. Rio de Janeiro: Forense, 2015.

BAPTISTA, Luiz Olavo. A “joint venture” - uma perspectiva comparatista. Revista de Direito Mercantil - Industrial, Econômico e Financeiro, São Paulo, n. 42, p. 40-59, 1981.

BARBOSA FILHO, Marcelo Fortes. Código civil comentado: doutrina e jurisprudência. Coordenação de Cezar Peluso. 3. ed. São Paulo: Manole, 2009.

BARBOSA, Hermano Notaroberto. Tributação das reorganizações de fundos de investimento. In: CASTRO, Leonardo Freitas de Moraes (Coord.). Mercado financeiro e de capitais: regulação e tributação. São Paulo: Quartier Latin, 2015. p. 1143-1163.

BARRETO FILHO, Oscar. Regime jurídico das sociedades de investimento (“investment trust”). São Paulo: Max Limonad, 1956. 
BARRETO, Aires Fernandino. ISS - consórcio para obras de construção civil solidariedade passiva das empresas consorciadas. Revista Dialética de Direito Tributário, São Paulo, n. 43, p. 164-184, 1999.

ISS na Constituição e na lei. 3. ed. São Paulo: Dialética, 2009.

BARRETO, Paulo Ayres. Juros sobre o capital próprio: não incidência de PIS e COFINS. Revista de Direito Tributário. São Paulo: Malheiros, n. 100, p. 130-139, 2008.

Planejamento tributário: limites normativos. São Paulo: Noeses, 2016.

BECHO, Renato Lopes. "Considerações sobre a obrigação tributária principal e acessória. Revista Dialética de Direito Tributário. São Paulo: Dialética, n. 230, p. 149-158, 2014.

BECKER, Alfredo Augusto. Teoria Geral do Direito Tributário. São Paulo: Saraiva, 1963.

BECKER, Valter Carlos E. As sociedades em conta de participação em face do imposto de renda. Rio de Janeiro: Revista Forense, v. 174, p. 478-480, 1957.

BEISSE, Heinrich. O critério econômico na interpretação das leis tributárias segundo a mais recente jurisprudência alemã. In: MACHADO, Brandão (Coord.). Direito

Tributário: estudos em homenagem ao Prof. Ruy Barbosa Nogueira. São Paulo: Saraiva, 1984. p. 5-39.

BERTHOLINI, Artemio. Contribuição ao estudo das implicações contábeis com as sociedades de propósito especial (SPE). 2004. 109 f. Dissertação (Mestrado em Ciências Contábeis e Financeiras) - Pontifícia Universidade Católica de São Paulo, São Paulo, 2004.

BIANCO, João Francisco. Aparência econômica e natureza jurídica. In: MOSQUERA, Roberto Quiroga; LOPES, Alexsandro Broedel (Coords.). Controvérsias jurídicocontábeis (aproximações e distanciamentos). São Paulo: Dialética, 2010. p. 174-184.

Transparência fiscal internacional. São Paulo: Dialética, 2007.

BIFANO, Elidie Palma. O mercado financeiro e o imposto sobre a renda. 2. ed. São Paulo: Quartier Latin, 2011.

BORBA, José Edwaldo Tavares. Direito Societário. 17. ed. São Paulo: Atlas, 2019.

Direito Societário. 6. ed. Rio de Janeiro: Renovar, 2001.

BORGES, José Eunápio. Curso de Direito Comercial Terrestre. 3. ed. Rio de Janeiro: Forense, 1967.

BOSELLO, Furio. A formulação da norma tributária e as categorias jurídicas civilísticas. In: MACHADO, Brandão (Coord.). Direito Tributário: estudos em homenagem ao Prof. Ruy Barbosa Nogueira. São Paulo: Saraiva, 1984. p. 43-58. 
BOTREL, Sérgio. Ato constitutivo das sociedades. In: COELHO, Fábio Ulhoa (Coord.). Tratado de Direito Comercial: introdução ao direito comercial e teoria geral das sociedades. v. 1. São Paulo: Saraiva, 2015. p. 327-358.

BOZZA, Fábio Piovesan. Sociedade em conta de participação: natureza, regime jurídico e tributação pelo imposto de renda. Revista Dialética de Direito Tributário, São Paulo: Dialética, n. 145, p. 36-46, 2007.

BRAGA, Bruno César Maciel. Sociedade de propósito específico e sociedade em conta de participação: novas reflexões. Revista de Direito Empresarial - RDEmp, Belo Horizonte: Fórum, n. 2, maio/ago. 2012. Disponível em:

<http://www.bidforum.com.br/PDI0006.aspx?pdiCntd=81407>. Acesso em: 22 jun. 2019.

BRANCHER, Paulo Marcos Rodrigues. Da conta de participação: inovações decorrentes do Projeto de Código Comercial e aplicação subsidiária das normas da sociedade limitada. In: COELHO, Fábio Ulhoa; LIMA, Tiago Asfor Rocha; NUNES, Marcelo Guedes (Coords.). Reflexões sobre o Projeto de Código Comercial. São Paulo: Saraiva, 2013. p. 299-310.

. Sociedade em conta de participação. In: COELHO, Fábio Ulhoa (Coord.).

Tratado de Direito Comercial: tipos societários, sociedade limitadas e sociedade anônima, v. 2. São Paulo: Saraiva, 2015. p. 29-44.

BULGARELLI, Waldirio. Manual das sociedades anônimas. 12. ed. São Paulo: Atlas, 2001.

. Sociedades, empresa e estabelecimento. São Paulo: Atlas, 1980.

BULHÕES PEDREIRA, José Luiz. Imposto sobre a Renda - Pessoas Jurídicas. v. 1. Rio de Janeiro: Justec, 1979.

CAMARGO, Ruy Junqueira de Freitas. Sociedade em conta de participação. Justitia, São Paulo: Ministério Público do Estado de São Paulo, v. 69, p. 260-262, 1970.

CAMPINHO, Sérgio. O Direito de Empresa à luz do Código Civil. 12. ed. Rio de Janeiro: Renovar, 2011.

CANTO, Gilberto de Ulhôa. Legislação tributária, sua vigência, sua eficácia, sua aplicação, interpretação e integração. Revista Forense, v. 267, p. 25-30, 1975.

CAROTA, José Carlos. A sociedade em conta de participação e o lucro presumido. Revista Autônoma de Direito Privado, Curitiba: Juruá, n. 5, p. 229-245, 2008.

CARRAZZA, Roque Antônio. Curso de Direito Constitucional Tributário. 30. ed. São Paulo: Malheiros, 2015.

Imposto sobre a renda: perfil constitucional e temas específicos. 3. ed. São Paulo: Malheiros, 2009.

CARVALHO DE MENDONÇA, José Xavier. Sociedade em conta de participação e locação de serviços. In: REBELLO, Edgardo de Castro. Pareceres: Sociedades. v. 2. Rio de Janeiro: Freitas Bastos, 1934. p. 347-354. 
. Tratado de Direito Comercial Brasileiro. v. 3, livro II - Dos comerciantes e seus auxiliares - Parte III - Das sociedades comerciais. Rio de Janeiro: Freitas Bastos, 1933.

Tratado de Direito Comercial Brasileiro. v. 4, livro II - Dos comerciantes e seus auxiliares - Parte III - Das sociedades comerciais. Rio de Janeiro: Freitas Bastos, 1937.

CARVALHO, João Rafael L. Gândara de. Forma e substância no direito tributário: legalidade, capacidade contributiva e planejamento fiscal. São Paulo: Almedina, 2016.

CARVALHO, Mário Tavernard Martins de. Fundos de investimento: aspectos polêmicos. In: FREITAS, Bernardo Vianna; VERSIANI, Fernanda Valle (Coords.). Fundos de investimentos: aspectos jurídicos, regulamentares e tributários. São Paulo: Quartier Latin, 2015. p. 15-33.

CARVALHO, Paulo de Barros. A relação jurídica tributária e as impropriamente chamadas 'obrigações acessórias'. Revista de Direito Público, São Paulo: Revista dos Tribunais, n. 17, p. 381-386, 1971.

Curso de Direito Tributário. 16. ed. São Paulo: Saraiva, 2004.

CARVALHOSA, Modesto. Comentários à Lei de Sociedades Anônimas - Artigos $1^{\circ}$ a 74. v. 1, 3. ed. São Paulo: Saraiva, 2000.

Saraiva, 1998.

Comentários à lei de sociedades anônimas - Artigos 138 a 205. v. 3. São Paulo:

Comentários à lei de sociedades anônimas - Artigos 243 a 300. t. 2, v. 4. São Paulo: Saraiva, 1998.

CASQUET, Pedro Guilherme Modenese. A obrigatoriedade de inscrição das Sociedades em Conta de Participação (SCP) perante o Cadastro Nacional das Pessoas Jurídicas (CNPJ) e o sigilo das informações relativas ao sócio participante. Checkpoint, São Paulo:

Thomson Reuters, 23 dez. 2014. Disponível em:

<http://artigoscheckpoint.thomsonreuters.com.br/a/6ocl/a-obrigatoriedade-de-inscricaodas-sociedades-em-conta-de-participacao-scp-perante-o-cadastro-nacional-das-pessoasjuridicas-cnpj-e-o-sigilo-das-informacoes-relativas-ao-socio-participante-pedro $>$. Acesso em: 02 dez. 2019.

CATAPANI, Márcio Ferro. Os contratos associativos. In: FRANÇA, Erasmo Valladão Azevedo e Novaes (Coord.). Direito Societário contemporâneo I. São Paulo: Quartier Latin, 2009. p. 87-103.

CHARNESKI, Heron. Normas internacionais de contabilidade e direito tributário brasileiro. São Paulo: Quartier Latin, 2018.

COELHO, Antonio Carlos; MARTINS, Eliseu. Análise das demonstrações financeiras de bancos estatais brasileiros em face do postulado da entidade. Revista de Economia e Administração, São Paulo, v. 5, p. 61-81, jan./mar. 2006. 
COELHO, Fábio Ulhoa. Curso de Direito Comercial: direito de empresa. 16. ed. São Paulo: Saraiva, 2012.

. Princípios do Direito Comercial: com anotações ao Projeto de Código

Comercial. São Paulo: Saraiva, 2012.

CÔELHO, Sacha Calmon Navarro; CÔELHO, Eduardo Junqueira. PIS/Cofins: não incidência sobre valores recebidos a título de juros sobre o capital próprio. In: GAUDÊNCIO, Samuel Carvalho; PEIXOTO, Marcelo Magalhães (Coords.).

Fundamentos do PIS e da Cofins e o regime da não-cumulatividade. São Paulo: MP, 2007. p. 397-417.

; DERZI, Misabel Abreu Machado. Intributabilidade pelo IPTU dos portos cedidos a empresas delegatárias de serviços públicos. Revista Dialética de Direito Tributário. São Paulo: Dialética, n. 163, p. 147-160, 2009.

COMPARATO, Fábio Konder. Os grupos societários na nova Lei de Sociedades por Ações. Revista de Direito Mercantil - Industrial, Econômico e Financeiro, São Paulo, n. 23, p. 91-107, 1976.

; SALOMÃO FILHO, Calixto. O poder de controle na sociedade anônima. 4. ed. Rio de Janeiro: Forense, 2005.

CORRÊA-LIMA, Sérgio Mourão; PIMENTA, Vinícius Rodrigues. Fundos de investimento. In: WALD, Arnoldo; GONÇALVES, Fernando; SOARES DE CASTRO, Moema Augusta (Coords.); FREITAS, Bernardo Vianna; CARVALHO, Mário Tavernard Martins de (Orgs.). Sociedades anônimas e mercado de capitais - homenagem ao Prof. Osmar Brina Corrêa-Lima. São Paulo: Quartier Latin, 2011. p. 653-678.

COSTA, Alcides Jorge. Direito Tributário e Direito Privado. In: OLIVEIRA, Ricardo Mariz de; COSTA, Sérgio de Freitas (Coords.). Diálogos póstumos com Alcides Jorge Costa. São Paulo: IBDT, 2017. p. 87-101.

COSTA, José Maria da. A sociedade em conta de participação no direito de empresa do código civil de 2002. 2006. 310 f. Dissertação (Mestrado em Direito Civil) - Pontifícia Universidade Católica de São Paulo, São Paulo, 2006.

CUNHA GONÇALVES, Luís da. Da conta em participação. 2. ed. Coimbra: Coimbra, 1923.

DERZI, Misabel Abreu Machado. Nota de Atualização. In: BALEEIRO, Aliomar. Direito Tributário Brasileiro. 13. ed. Atualizada por Misabel Abreu Machado Derzi. Rio de Janeiro: Forense, 2015.

DINIZ, Rodrigo Pará. Fundos de investimento no direito brasileiro: aspectos tributários e questões controversas em matéria fiscal. São Paulo: Almedina, 2014.

DÓRIA, Antônio Roberto Sampaio. Da lei tributária no tempo. São Paulo: Obelisco, 1968.

Prefácio. In: DÓRIA, Antônio Roberto Sampaio (Coord.). Incentivos fiscais para

o desenvolvimento. São Paulo: José Bushatsky, 1971. p. 9-10. 
EIZIRIK, Nelson. A lei das S/A comentada: Artigos 189 a 300. v. 3. São Paulo: Quartier Latin, 2011.

. Notas sobre a sociedade em conta de participação. Direito Societário - Estudos e Pareceres. São Paulo: Quartier Latin, 2015. p. 735-758.

FAJERSZTAJN, Bruno et al. Segurança jurídica em matéria tributária. In: MARTINS, Ives Gandra da Silva (Coord.). Segurança jurídica em matéria tributária. Pesquisas Tributárias. 4. ed. Porto Alegre: Coedição CEU, IICS e LexMagister, 2016. p. 327-382.

FARIA, Renato Vilela; SANTOS, Ricardo Augusto Alves dos Santos. Regime tributário da SCP e análise de casos: (i) regime pool e (ii) dação em pagamento. In: FARIA, Renato Vilela; CASTRO, Leonardo Freitas de Moraes (Coords.). Operações imobiliárias: estruturação e tributação. São Paulo: Saraiva, 2016. p. 545-567.

FATF/OECD. FATF Guidance: transparency and beneficial Ownership. Paris: FATF/OECD, 2014.

The FATF recommendations: international standards on combating money laundering and the financing of terrorism and proliferation. Paris: FATF/OECD, 2018.

FÉRES, Marcelo Andrade. Sociedade em comum: disciplina jurídica e institutos afins. São Paulo: Saraiva, 2011.

FERNANDES, Edison Carlos. Direito e contabilidade: fundamentos do direito contábil. São Paulo: Trevisan, 2015.

FERRARA, Francisco. A simulação dos negócios jurídicos. São Paulo: Saraiva, 1939.

FERREIRA, Waldemar. Compêndio de sociedades mercantis. v. 1. Rio de Janeiro: Livraria Freitas Bastos, 1940.

Instituições de Direito Comercial: O estatuto do comerciante e da sociedade mercantil. v. 1. Rio de Janeiro: Livraria Freitas Bastos, 1944.

Tratado de Direito Comercial: o estatuto da sociedade de pessoas. v. 3. São Paulo: Saraiva, 1961.

FERRO-LUZZI, Paolo. I contratti associativi. Milano: Giuffrè, 2001.

FRANÇA, Erasmo Valladão Azevedo e Novaes. A natureza jurídica dos fundos de investimento. Conflito de interesses apurado pela própria assembleia de cotista. Quórum qualificado para destituição de administrador de fundo. In: (Coord.). Temas de Direito Societário, Falimentar e Teoria da Empresa. São Paulo: Malheiros, 2009. p. 185-215.

A sociedade em comum. São Paulo: Malheiros, 2013.

. Sociedade simples. In: GONÇALVES NETO, Alfredo de Assis; FRANÇA, Erasmo Valladão Azevedo e Novaes. CARVALHOSA, Modesto (Coords.). Tratado de Direito Empresarial. v. 2. Empresa individual de responsabilidade limitada e sociedade de pessoas. São Paulo: Revista dos Tribunais, 2016. p. 259-332. 
; ADAMEK, Marcelo Vieira Von. Affectio societatis: um conceito jurídico superado no moderno Direito Societário. In: FRANÇA, Erasmo Valladão Azevedo e Novaes (Coords.). Direito Societário contemporâneo I. São Paulo: Quartier Latin, 2009. p. 131-161.

FRANCO, Hilário. Contabilidade geral. 23. ed. São Paulo: Atlas, 1996.

FREITAS, Ricardo de Santos. Natureza jurídica dos fundos de investimento. São Paulo: Quartier Latin, 2006.

. Natureza jurídica dos fundos de investimento imobiliários e regimes de tributação. In: MOSQUERA, Roberto Quiroga (Coord.). O direito tributário e o mercado financeiro e de capitais. São Paulo: Dialética, 2009. p. 432-463.

GALHARDO, Luciana Rosanova; LOPES JUNIOR, Jorge Ney de Figueirêdo. Tributação dos fundos de investimento pelo imposto sobre a renda. In: MOSQUERA, Roberto Quiroga (Coord.). O direito tributário e o mercado financeiro e de capitais. São Paulo: Dialética, 2009. p. 303-323.

GALIZZI, Gustavo Oliva. A sociedade em conta de participação como subespécie do gênero joint venture. Revista de Direito Mercantil - Industrial, Econômico e Financeiro, São Paulo, n. 135, p. 206-218, 2004.

. Sociedade em Conta de Participação. Belo Horizonte: Mandamentos, 2008.

GELCKE, Ernesto Rubens et al. Manual de contabilidade das sociedades por ações: aplicável às demais sociedades. 7. ed. São Paulo: Atlas, 2007.

. Manual de contabilidade societária: aplicável a todas as sociedades: de acordo com as normas internacionais e do CPC. 2. ed. São Paulo: Atlas, 2013.

GHIDINI, Mario. L'associazione in partecipazione. Milão: Giuffrè, 1959.

GODOI, Marciano Seabra de. Estudo comparativo sobre o combate ao planejamento tributário abusivo na Espanha e no Brasil. Sugestão de alterações legislativas no ordenamento brasileiro. Revista de Informação Legislativa, Brasília, v. 194, p. 117-146, 2012.

GOMES, Orlando. Contratos. 18. ed. Atualização e notas de Humberto Theodoro Júnior. Rio de Janeiro: Forense, 1998.

. Introdução ao Direito Civil. 14. ed. Rio de Janeiro: Forense, 1999.

GONÇALVES NETO, Alfredo de Assis. Conteúdo do ato constitutivo. In: FRANÇA, Erasmo Valladão Azevedo e Novaes. CARVALHOSA, Modesto (Coords.). Tratado de Direito Empresarial. Empresa individual de responsabilidade limitada e sociedade de pessoas. v. 2. São Paulo: Revista dos Tribunais, 2016. p. 169-202.

. Direito de empresa: comentários aos artigos 966 a 1195 do Código Civil. 9. ed. São Paulo: Thomson Reuters Brasil, 2019. 
. Noções gerais. In: ; FRANÇA, Erasmo Valladão Azevedo e Novaes; CARVALHOSA, Modesto (Coords.). Tratado de Direito Empresarial. Empresa individual de responsabilidade limitada e sociedade de pessoas. v. 2. São Paulo: Revista dos Tribunais, 2016. p. 89-113.

O ato constitutivo e seus elementos essenciais. In: ; FRANÇA, Erasmo Valladão Azevedo e Novaes; CARVALHOSA, Modesto (Coords.). Tratado de Direito Empresarial. Empresa individual de responsabilidade limitada e sociedade de pessoas. v. 2. São Paulo: Revista dos Tribunais, 2016. p. 131-168.

Sociedade em conta de participação. In: ; FRANÇA, Erasmo Valladão Azevedo e Novaes; CARVALHOSA, Modesto (Coords.). Tratado de Direito Empresarial. Empresa individual de responsabilidade limitada e sociedade de pessoas. v. 2. São Paulo: Revista dos Tribunais, 2016. p. 247-262.

GONÇALVES, Alexandre T. Navarro Pereira. Tributação das operações imobiliárias. São Paulo: Quartier Latin, 2007.

GRECO, Marco Aurélio. Planejamento tributário. 4. ed. São Paulo: Quartier Latin, 2019.

GUEDES, Vinícius Mancini. Sociedade e comunhão - os fundos de investimento. In: FRANÇA, Erasmo Valladão Azevedo e Novaes (Coord.). Direito Societário contemporâneo I. São Paulo: Quartier Latin, 2009. p. 67-86.

GUERREIRO, José Alexandre Tavares. Comentário de jurisprudência. São Paulo: Revista de Direito Mercantil, Industrial, Econômico e Financeiro, n. 54, p. 126-130, 1984.

GUSMÃO, João Manoel Carlos de. As operações em conta de participação assumem o caracter de verdadeira sociedade? Quaes os elementos característicos das operações em conta de participação? O Direito: revista mensal de legislação, doutrina e jurisprudência, Rio de Janeiro, n. 29, p. 333-340, 1882.

GUTIERREZ, Miguel Delgado. Planejamento tributário - elisão e evasão fiscal. São Paulo: Quartier Latin, 2006.

HARTZ, Wilhelm. Interpretação da lei tributária: conteúdo e limites do critério econômico. Tradução, prefácio e notas de Brandão Machado. São Paulo: Resenha Tributária, 1993.

HIGUCHI, Hiromi. Imposto de renda das empresas: interpretação e prática. 11. ed. São Paulo: Atlas, 1986.

Atlas, 1987.

Imposto de renda das empresas: interpretação e prática. 12. ed. São Paulo:

Imposto de renda das empresas: interpretação e prática. Atualizado até 15-022017. São Paulo: IR Publicações, 2017. Disponível em: <http://ibdt.org.br/site/wpcontent/uploads/2019/03/IR2017.pdf>. Acesso em: 02 ago. 2019.

HILDEBRAND, Lucas Fajardo Nunes. Patrimônio, patrimônio separado ou especial, patrimônio autônomo. In: FRANÇA, Erasmo Valladão Azevedo e Novaes (Coord.). Direito Societário Contemporâneo I. São Paulo: Quartier Latin, 2009. p. 263-279. 
HÜBERT, Ivens Henrique. Capital Social. In: COELHO, Fábio Ulhoa (Coord.). Tratado de Direito Comercial: introdução ao Direito Comercial e teoria geral das sociedades, v. 1. São Paulo: Saraiva, 2015. p. 382-411.

HUCK, Hermes Marcelo. Pactos societários leoninos. Revista dos Tribunais, São Paulo, v. 760, p. 64-73, 1999.

IFRS. The Annotated IFRS Standards. Part B: Standards issued at 1 January 2018 reflecting changes not yet required. London: IFRS, 2018.

LACERDA, Galeno. Sociedade em conta de participação. In: Direito Comercial: sociedades mercantis - casos selecionados. v. 9. Rio de Janeiro: Forense, 2004. p. 135-163.

LAMY FILHO, Alfredo; PEDREIRA, José Luiz Bulhões. Direito das companhias. Rio de Janeiro: Forense, 2017.

LARENZ, Karl. Metodologia da Ciência do Direito. 6. ed. Tradução de José Lamengo. Lisboa: Fundação Calouste Gulbenkian, 2012.

LE CONTE, Pierre. Les associations en participation. Paris: Imprimerie Levé, 1913.

LEÃES, Luiz Gastão Paes de Barros. Direito do acionista ao dividendo. São Paulo: Obelisco, 1969.

LOPES, Alexsandro Broedel; MOSQUERA, Roberto Quiroga. O direito contábil. Fundamentos conceituais, aspectos da experiência brasileira e implicações. In: MOSQUERA, Roberto Quiroga; LOPES, Alexsandro Broedel (Coords.). Controvérsias jurídico-contábeis (aproximações e distanciamentos). São Paulo: Dialética, 2010. p. 5681.

LOPES, Mauro Brandão. A sociedade em conta de participação. São Paulo: Saraiva, 1990.

MACHADO SEGUNDO, Hugo de Brito. As liberdades econômica e profissional e os cadastros de contribuintes. Revista Dialética de Direito Tributário, São Paulo: Dialética, n. 67, p. 73-80, 2001.

MACHADO, Brandão. Prefácio. In: HARTZ, Wilhelm. Interpretação da lei tributária: conteúdo e limites do critério econômico. Tradução, prefácio e notas de Brandão Machado. São Paulo: Resenha Tributária, 1993. p. 5-27.

MACHADO, Hugo de Brito. Comentários ao Código Tributário Nacional. v. 2. São Paulo: Atlas, 2004.

MACHADO, Raquel Cavalcanti Ramos. Competência tributária: entre a rigidez do sistema e a atualização interpretativa. São Paulo: Malheiros, 2014.

MAEDA, Renata de Souza. Sociedade em conta de participação: aspectos gerais e responsabilidades. 2011. 48 f. Monografia (Especialização em Contratos e Responsabilidade Civil) - Instituto Brasiliense de Direito Público - IDP, Brasília, 2011. 
MALCHER FILHO, Clovis Cunha da Gama. Sociedades empresárias menores. In: COELHO, Fábio Ulhoa (Coord.). Tratado de Direito Comercial: tipos societários, sociedade limitadas e sociedade anônima. v. 2. São Paulo: Saraiva, 2015. p. 13-28.

MARION, José Carlos. Uma contribuição à contabilidade da sociedade em conta de participação aplicada a empreendimentos florestais. 1989. 220 f. Tese (Livre-docência do Departamento de Atuária da Faculdade de Economia e Administração) - Universidade de São Paulo, São Paulo, 1989.

; BERTHOLINI, Artemio. A teoria contábil e as sociedades em conta de participação. Revista do Conselho Regional de Contabilidade do Rio Grande do Sul, v. 62, p. 16-25, ago. 1990.

MARTINS, Eliseu; DINIZ, Josedilton Alves; MIRANDA, Gilberto José. Análise avançada das demonstrações contábeis: uma abordagem crítica. 2. ed. São Paulo: Atlas, 2018.

MARTINS, Fran. Curso de Direito Comercial. Atual. Carlos Henrique Abrão. 38. ed. Rio de Janeiro: Forense, 2015.

MARTINS, Ives Gandra da Silva. Obrigações acessórias no interesse da fiscalização e da livre concorrência entre empresas - Direito assegurado ao fisco pelas leis suprema e complementar. Revista Fórum de Direito Tributário, Belo Horizonte: Fórum, n. 8, p. 143-161, 2004.

Sociedade em conta de participação constituída nos exatos termos dos artigos 981, 991 a 996 e 997, inciso V, do Código Civil com bens e serviços - desconsideração da forma pela SRFB - maculação dos artigos 109 e 110 do CTN. Revista Dialética de Direito Tributário, São Paulo: Dialética, n. 231, p. 145-164, 2014.

MARTINS, Ricardo Lacaz. Tributação da renda imobiliária. São Paulo: Quartier Latin, 2011.

MARTINS, Simone; SEBBEN, Vanessa. A sociedade em conta de participação e a joint venture como ferramentas de planejamento tributário. Revista CEJ, Brasília, n. 54, p. 8187, 2011.

MÉLEGA, Luiz. As sociedades em conta de participação e o imposto sobre a renda. Suplemento Tributário da Revista LTr, São Paulo, v. 10, p. 55-60, 1988.

MELLO FRANCO, Vera Helena de. As sociedades de pessoas na atualidade: uma visão comparativa crítica. Revista de Direito Mercantil - Industrial, Econômico e Financeiro, São Paulo, n. 157, p. 93-111, 2011.

MELO, José Eduardo Soares de. Imposto de renda na fonte - Decretos-leis n. 1979 e 1980, de 22.12.82. Suplemento Tributário da Revista LTr, São Paulo, v. 22, p. 53-54, 1983.

MIRANDA, Francisco Cavalcanti Pontes de. Tratado de Direito Privado: Parte Especial. t. 38. Campinas: Bookseller, 2005.

Tratado de Direito Privado: Parte Especial. t. 49, 3. ed. Rio de Janeiro: Borsoi, 
1970.

. Tratado de Direito Privado: Parte Geral. t. 1, 3. ed. Rio de Janeiro: Borsoi,

MORAES, Bernardo Ribeiro. Compêndio de Direito Tributário. Rio de Janeiro: Forense, 1987.

MORAES, Eduardo Peixoto Menna Barreto. Sociedade em conta de participação: riscos de descaracterização do tipo societário e suas consequências. 2015. 108 f. Dissertação (Mestrado em Direito dos Negócios) - Escola de Direito de São Paulo da Fundação Getulio Vargas, São Paulo, 2015.

MORAES, Francisco Chagas de. A equiparação da sociedade em conta de participação à pessoa jurídica. Suplemento Tributário da Revista LTr, São Paulo, v. 65, p. 363-364, 1987.

MORAIS, Antão de. Sociedade em conta de participação - 'Investment trusts' -

Sociedades de crédito, financiamento ou investimentos. Revista Forense, Rio de Janeiro, v. 165, p. $70-73,1956$.

MOSQUERA, Roberto Quiroga. O regime jurídico-tributário das participações societárias - ganho de capital, juros sobre o capital próprio e dividendos. In: MOSQUERA, Roberto Quiroga (Coord.). O direito tributário e o mercado financeiro e de capitais. São Paulo: Dialética, 2009. p. 415-431.

. Renda e proventos de qualquer natureza: o imposto e o conceito constitucional. São Paulo: Dialética, 1996.

1999.

. Tributação no mercado financeiro e de capitais. 2. ed. São Paulo: Dialética,

MOYSÉS, Mauricio Boudakian. As sociedades simples. In: FRANÇA, Erasmo Valladão Azevedo e Novaes (Coord.). Direito Societário contemporâneo I. São Paulo: Quartier Latin, 2009. p. 525-550.

MÜSSNICH, Francisco Antunes Maciel; PERES, Fábio Henrique. Notas acerca das quotas no Direito Brasileiro. In: AZEVEDO, Luís André N. de Mora; CASTRO, Rodrigo R. Monteiro (Coords.). Sociedade Limitada contemporânea. São Paulo: Quartier Latin, 2013. p. 93-114.

NABAIS, José Casalta. Direito Fiscal. 8. ed. Coimbra: Almedina, 2015.

NASCIMENTO, João Pedro Barroso do. Sociedade em conta de participação. Jota, Brasília, 06 nov. 2019. Disponível em:

<https://www.jota.info/paywall?redirect_to=//www.jota.info/opiniao-eanalise/artigos/sociedade-em-conta-de-participacao-06112019>. Acesso em: 13 nov. 2019.

NETO, Luís Flávio. Entre o amor e a indiferença: vamos discutir a relação? O relacionamento do direito tributário com o direito privado e o caso da permuta de ações sem torna. Revista Direito Tributário Atual, São Paulo: IBDT, v. 38, p. 92-116, 2017. 
NICACIO, Antonio. Imposto de renda - pessoa jurídica - sociedade em conta de participação - normas de tributação - IN n. 49/87. Suplemento Tributário da Revista LTr, São Paulo, v. 37, p. 211-213, 1987.

NOGUEIRA, Ruy Barbosa. Curso de Direito Tributário. 14. ed. São Paulo: Saraiva, 1995.

OLIVEIRA, Ricardo Mariz de. A simulação no Código Tributário Nacional e na prática. Revista Direito Tributário Atual, São Paulo: Dialética e IBDT, n. 27, p. 561-579, 2012.

. Elisão e evasão fiscal. In: MARTINS, Ives Gandra da Silva (Coord.). Caderno de Pesquisas Tributárias. v. 13. São Paulo: Coedição Centro de Extensão Universitária CEU e Resenha Tributária, 1988. p. 147-192.

Fundamentos do imposto de renda. São Paulo: Quartier Latin, 2008.

Guia IOB de Imposto de Renda da Pessoa Jurídica comentado e atualizável. Procedimento IV.5. v. 2. São Paulo: IOB, 2014.

Guia IOB de Imposto de Renda da Pessoa Jurídica comentado e atualizável. Procedimento X.7. v. 2. São Paulo: IOB, 2014.

. Inexistência de sucessão tributária relativa ao imposto de renda no caso de simples aquisição de imóvel comercial, exploração da mesma atividade no local e anterior existência de sociedade em conta de participação como antigo proprietário. Revista Direito Tributário Atual, São Paulo: IBDT, v. 6, p. 1431-1495, 1986.

Jurisprudência do imposto de renda comentada. São Paulo: CTE, 1976.

. Juros de remuneração do capital próprio. Revista Direito Tributário Atual, São Paulo: Dialética, n. 15, p. 114-126, 1998.

. O empresário, a sociedade empresária, a sociedade simples e a responsabilidade tributária perante o Código Tributário Nacional - CTN e o Código Civil de 2002. Revista de Direito Tributário, São Paulo: Malheiros, v. 90, p. 35-66, 2003.

. Solidariedade tributária passiva e responsabilidade tributária passiva características e inexistência simultânea. In: MARTINS, Ives Gandra da Silva (Coord.). Grupos Econômicos. Porto Alegre: CEU; LexMagister; IICS, 2015. p. 79-150.

PAULSEN, Leandro. Curso de Direito Tributário Completo. 6. ed. Porto Alegre: Livraria do Advogado, 2014.

PEDÃO, Ana Cláudia; VALLE, João Carlos Mettlach Pinter Mateus Telles; CATALANO, Victoria Guidette. Embate entre duas lógicas diversas: o uso fraudulento da sociedade em conta de participação. Revista de Direito Mercantil - Industrial, Econômico e Financeiro, São Paulo, n. 161/162, p. 204-219, 2012.

PELLEGRINI, Luiz Fernando Gama. Sociedade em conta de participação - sócio oculto imposto sobre a renda na fonte. Suplemento Tributário da Revista LTr, São Paulo, v. 14, p. 35-36, 1983. 
PEREIRA, Caio Mario da Silva. Instituições de direito civil. v. 1, 9. ed. Rio de Janeiro: Forense, 1986.

PICCHI, Flavio Augusto. A sociedade em conta de participação e os contratos de investimento coletivo: paralelismo e assimetria. Revista de Direito Mercantil Industrial, Econômico e Financeiro, São Paulo, n. 134, p. 193-205, 2004.

PIMENTA, Vinícius Rodrigues. Sociedade em conta de participação motivos para sua utilização. Revista da Faculdade de Direito da Universidade de Minas Gerais, Belo Horizonte, n. 47, p. 341-353, 2005.

PORTUGAL, Bernardo Lopes. A sociedade em conta de participação no Novo Código Civil e seus aspectos tributários. In: RODRIGUES, Frederico Viana (Coord.). Direito de empresa no novo Código Civil. Rio de Janeiro: Forense, 2004. p. 157-164.

RAMIRES, Rogério. A sociedade em conta de participação no Direito Brasileiro. 2. ed. Coimbra: Almedina, 2013.

REQUIÃO, Rubens. Conta de participação, consórcio e parceria - Formas associativas não personalizadas. Revista de Direito Mercantil - Industrial, Econômico e Financeiro, São Paulo, n. 105, p. 37-42, 1997.

Curso de Direito Comercial. v. 1. 26. ed. São Paulo: Saraiva, 2009.

Curso de Direito Comercial. v. 2. 26. ed. São Paulo: Saraiva, 2009.

ROCHA JUNIOR, Arlindo Luiz; ARAUJO, Elaine Cristina de; SOUZA, Katia Luiza Nobre de. Sociedade em conta de participação. São Paulo: IOB SAGE, 2015.

ROCHA, João Luiz Coelho da. Cofins, contribuintes, cumulatividade - Elisão Lícita. Revista Dialética de Direito Tributário, São Paulo: Dialética, n. 88, p. 46-51, 2003.

RODRIGUES, Silvio. Direito Civil - Dos contratos e das declarações unilaterais da vontade. v. 3, 28. ed. São Paulo: Saraiva, 2002.

ROTHMANN, Gerd Willi. Afinal, o planejamento tributário pode ser criminoso? In: PRETO, Raquel Elita Alves. Tributação Brasileira em Evolução: Estudos em Homenagem ao Professor Alcides Jorge Costa, São Paulo: IASP, 2015. p. 675-698.

SALGADO, Paulo Cavalcanti. Das sociedades em participação no Direito Comercial brasileiro. Recife: Imprensa Industrial, 1913.

SALOMÃO FILHO, Calixto. O novo Direito Societário: eficácia e sustentabilidade. 5. ed. São Paulo: Saraiva, 2019.

SANTOS NETO, Correia dos. Contrato de consórcio e de associação em participação. Coimbra: Coimbra, 1986.

SANTOS, Ramon Tomazela. A avaliação de investimentos pelo método da equivalência patrimonial e os impactos tributários das novas regras contábeis. Revista Tributária e de Finanças Públicas, São Paulo, v. 112, p. 269-293, 2013. 
SARQUIS, Raquel Wille. Eliminação do método de consolidação proporcional para reconhecimento dos investimentos em joint ventures: quais os impactos para as empresas do mercado brasileiro? 2014. 310 f. Dissertação (Mestrado em Controladoria e Contabilidade) - Faculdade de Economia, Administração e Contabilidade, Universidade de São Paulo, São Paulo, 2014. Disponível em:

<http://www.teses.usp.br/teses/disponiveis/12/12136/tde-26032015-161923/en.php>. Acesso em: 29 maio 2019.

SCAFF, Fernando Facury. Tributação de sociedades em conta de participação. Revista Dialética de Direito Tributário. São Paulo: Dialética, n. 157, p. 87-94, 2008.

SCALZILLI, João Pedro. Confusão patrimonial no Direito Societário. São Paulo: Quartier Latin, 2015. Latin, 2015.

Mercado de capitais: ofertas hostis e técnicas de defesa. São Paulo: Quartier ; SPINELLI, Luis Felipe. Sociedade em conta de participação. São Paulo: Quartier Latin, 2015.

SCHOUERI, Luís Eduardo. Direito Tributário. 8. ed. São Paulo: Saraiva, 2018.

Distribuição disfarçada de lucros. São Paulo: Dialética, 1996.

Juros sobre capital próprio: natureza jurídica e forma de apuração diante da 'nova contabilidade'. In: MOSQUERA, Roberto Quiroga; LOPES, Alexsandro Broedel (Coords.). Controvérsias jurídico-contábeis (aproximações e distanciamentos). v. 3. São Paulo: Dialética, 2012. p. 169-193.

. Normas tributárias indutoras e intervenção econômica. Rio de Janeiro: Forense, 2005.

Nova contabilidade e tributação: da propriedade à beneficial ownership. In: MOSQUERA, Roberto Quiroga; LOPES, Alexsandro Broedel (Coords.). Controvérsias jurídico-contábeis (aproximações e distanciamentos). v. 5. São Paulo: Dialética, 2014. p. 200-221.

Preços de transferência no Direito Tributário brasileiro. 3. ed. São Paulo: Dialética, 2013.

; BARBOSA, Mateus Calicchio. A persona e o direito: entre a realidade e a ficção das pessoas jurídicas. Revista Direito Tributário Atual, São Paulo: Dialética, v. 30, p. 251-273, 2014.

SIEIRO, Horacio D. Diaz. IFA Branch Report - Argentina. Cahier de Droit Fiscal International, Oslo, v. 67a, p. 71-91, 2002.

SILVA, Fabiana Carsoni Alves Fernandes da. Consórcios de empresas: aspectos jurídicos relevantes. São Paulo: Quartier Latin, 2015.

; COVIELLO FILHO, Paulo. Aplicação do Regime Especial de Tributação, instituído pela Lei n. 10931/2004, para receitas de venda de imóveis após a conclusão da 
obra objeto da incorporação imobiliária. Revista Fórum de Direito Tributário - RFDT, Belo Horizonte: Fórum, n. 86, p. 99-112, mar./abr. 2017.

SILVA, Oliveira e. Tratado das sociedades comerciais. Rio de Janeiro: Livraria Jacinto, 1942.

SOUSA, Rubens Gomes de. Compêndio de legislação tributária. São Paulo: Resenha Tributária, 1975.

. Imposto de renda. Rio de Janeiro: Edições Financeiras, 1955.

SOUZA, Mariana Campos de. Uso da sociedade em conta de participação para organizar interesses privados em contratações públicas. 2017. 125 f. Dissertação de Mestrado (Mestrado em Direito dos Negócios). São Paulo: Escola de Direito de São Paulo da Fundação Getulio Vargas, 2017.

SZTAJN, Rachel. Contrato de sociedade e formas societárias. São Paulo: Saraiva, 1989.

SZTAJN, Rachel. Comentário aos Artigos 887 a 926 e 966 a 1195. In:

FONSECA, Priscila Maria Pereira Correa da. Código Civil comentado: Direito de

Empresa. v. 11. Coordenação de Álvaro Villaça Azevedo. São Paulo: Atlas, 2008. passim.

TAKANO, Caio Augusto. Deveres instrumentais dos contribuintes: fundamentos e limites. São Paulo: Quartier Latin, 2017.

TEIXEIRA, Egberto Lacerda; GUERREIRO, José Alexandre Tavares. Das Sociedades Anônimas no Direito Brasileiro. v. 2. São Paulo: Jose Bushatsky, 1979.

TEODOROVICZ, Jeferson. História disciplinar do Direito Tributário Brasileiro. São Paulo: Quartier Latin, 2017.

TEPEDINO, Gustavo; BARBOZA, Heloisa Helena; MORAES, Maria Celina Bodin de. Código Civil Interpretado conforme a Constituição da República. v. 3, 2. ed. Rio de Janeiro: Renovar, 2014.

TESAURO, Francesco. Instituições de Direito Tributário. Tradução de Fernando Aurelio Zilveti e Laura Fiore Ferreira. São Paulo: IBDT, 2017.

TESSARI, Cláudio. Análise de caso real de autuação fiscal - sociedade em conta de participação (SCP) constituída com a finalidade de reduzir a carga tributária. Revista Dialética de Direito Tributário, São Paulo: Dialética, n. 210, p. 19-31, 2013.

TILBERY, Henry. Base econômica e efeito das isenções. In: DÓRIA, Antônio Roberto Sampaio (Coord.). Incentivos fiscais para o desenvolvimento. São Paulo: José Bushatsky, 1971. p. 11-68.

TIPKE, Klaus; LANG, Joachim. Direito Tributário (Steuerrecht). v. 1. Tradução da $18^{a}$ edição alemã, totalmente refeita, de Luiz Doria Furquim. Porto Alegre: Sergio Antonio Fabris, 2008. 
TOFFANELLO, Rafael Dias. Dedutibilidade do IRPJ e CSLL dos juros ao capital pagos por sociedade cooperativa aos seus cooperados. Revista Dialética de Direito Tributário, São Paulo: Dialética, n. 221, p. 117-128, 2014.

TOMAZETTE, Marlon. Curso de Direito Empresarial: Teoria Geral e Direito Societário. v. 1, 2. ed. São Paulo: Atlas, 2009.

TOMÉ, Fabiana Del Padre. Forma e conteúdo nas sociedades em conta de participação (SCP): análise dos efeitos jurídico-tributários. In: MOREIRA, André Mendes et al. O Direito Tributário: entre a forma e o conteúdo. São Paulo: Noeses, 2014. p. 377-397.

TORRES, Heleno Taveira. Direito Tributário e Direito Privado: autonomia privada, simulação e elusão tributária. São Paulo: Revista dos Tribunais, 2003.

IRPJ nas sociedades em conta de participação. In: ZILVETI, Fernando Aurelio; FAJERSZTAJN, Bruno; SILVEIRA, Rodrigo Maito da (Coords.). Direito Tributário: princípio da realização da renda - estudos em homenagem a Ricardo Mariz de Oliveira. São Paulo: IBDT, 2019. p. 329-362.

TORRES, Ricardo Lobo. Normas de interpretação e integração do Direito Tributário. 3. ed. Rio de Janeiro: Renovar, 2000.

. O princípio da proporcionalidade e as normas antielisivas no Código Tributário da Alemanha. Revista Direito Tributário Atual. v. 25. São Paulo: Dialética; IBDT, 2011. p. 121-131.

TRESSE, Vitor Schettino; MÜLLER, Juliana Martins de Sá. As peculiaridades da sociedade em conta de participação: por uma análise conforme seus fundamentos jurídicos. In: MACEI, Demetrius Nicheli; BENACCHIO, Marcelo; RIBEIRO, Maria de Fatima (Coords.). Direito empresarial. Florianópolis: CONPEDI, 2015. p. 143-170.

TUDISCO, Flávio. A causa dos negócios jurídicos, a prevalência da substância sobre a forma e o Direito Tributário brasileiro. Revista Direito Tributário Atual, São Paulo: IBDT; Dialética, v. 22, p. 207-218, 2008.

VALLES, Edgar. Consórcio, ACE e outras figuras. Coimbra: Almedina, 2007.

VANONI, Ezio. Natureza e interpretação das leis tributárias. Tradução de Rubens Gomes de Sousa. Rio de Janeiro: Financeiras, 1952.

VASCONCELOS, Paulo Alves de Sousa de. O contrato de consórcio no âmbito dos contratos de cooperação entre empresas. Coimbra: Coimbra, 1999.

VASCONCELOS, Pedro Pais de. Contratos atípicos. 2. ed. Coimbra: Almedina, 2009.

VELLOSO, Andrei Pitten. Conceitos e competências tributárias. São Paulo: Dialética, 2005.

VENOSA, Sílvio de Salvo. Direito Civil: parte geral. 8. ed. São Paulo: Atlas, 2008.

VERÇOSA, Haroldo Malheiros Duclerc; SZTAJN, Rachel. Contrato de sociedade: completamento. In: KUYVEN, Luiz Fernando Martins (Coord.). Temas essenciais de 
direito empresarial: estudos em homenagem a Modesto Carvalhosa. São Paulo: Saraiva, 2012. p. 624-638.

VIEIRA, Marcelo Lima. Moeda funcional: conceitos e aspectos práticos nas demonstrações financeiras das entidades decorrentes da não adoção do CPC 02 para fins de IRPJ e CSLL - Lei n. 12973/14. In: VIEIRA, Marcelo Lima; CARMIGNANI, Zabetta Macarini; BIZARRO, André Renato (Coords.). Lei n. 12973 - novo marco tributário: padrões internacionais de contabilidade. São Paulo: Quartier Latin, 2015. p. 239-261.

VIERLING-KOVAR, Emmanuelle. Le contrat de société en participation. 2013. 489 f. Tese (Doutorado em Direito Empresarial) - Université de Strasbourg, Strasburg, 2013.

VILANOVA, Lourival. As estruturas lógicas e o sistema do Direito Positivo. São Paulo: Max Limonad, 1997.

VIVANTE, Cesar. Tratado de Derecho Mercantil. v. 2. Las sociedades mercantiles. Tradução da $5^{\text {a }}$ edição italiana feita por Ricardo Espejo de Hinojosa. Madri: Editorial Reus, 1932.

WALD, Arnoldo. Comentários ao Código Civil. v. 14, livro II, do Direito de Empresa. Coordenação de Sálvio de Figueiredo. Rio de Janeiro: Forense, 2005.

. Curso de Direito Civil brasileiro: obrigações e contratos. 7. ed. São Paulo: Revista dos Tribunais, 1987.

. Da natureza jurídica do fundo imobiliário. Revista de Direito Mercantil Industrial, Econômico e Financeiro, São Paulo: Revista dos Tribunais, n. 80, p. 15-23, 1990.

. O Código Civil e o Projeto de Código Comercial. In: COELHO, Fábio Ulhoa; LIMA, Tiago Asfor Rocha; NUNES, Marcelo Guedes (Coords.). Reflexões sobre o Projeto de Código Comercial. São Paulo: Saraiva, 2013. p. 19-30.

WARDE JÚNIOR, Walfrido Jorge; JUNQUEIRA NETO, Ruy de Mello. Direito Societário aplicado: baseado nos precedentes das câmaras reservadas de Direito Empresarial do Tribunal de Justiça do Estado de São Paulo. São Paulo: Saraiva, 2014.

XAVIER, Alberto. Consórcio: natureza jurídica e regime tributário. Revista Dialética de Direito Tributário, São Paulo: Dialética, n. 64, p. 7-26, 2001.

. Natureza jurídico-tributária dos ‘juros sobre capital próprio’ face à lei interna e aos tratados internacionais. Revista Dialética de Direito Tributário, São Paulo, n. 21, p. 7-11, 1997. 2001.

. Tipicidade da tributação, simulação e norma antielisiva. São Paulo: Dialética,

YOSHIKAWA, Eduardo Henrique de Oliveira. Reflexos processuais da sociedade em conta de participação. Revista Dialética de Direito Processual, São Paulo: Dialética, n. 116, p. 30-43, 2012. 
ZANINI, Carlos Klein. Notas sobre o projeto de Código Comercial. In: KUYVEN, Luiz Fernando Martins (Coord.). Temas essenciais de direito empresarial: estudos em homenagem a Modesto Carvalhosa. São Paulo: Saraiva, 2012. p. 467-473.

ZILVETI, Fernando Aurelio. A evolução histórica da tributação: análise das estruturas socioeconômicas na formação do sistema tributário. São Paulo: Saraiva, 2017.

A tributação sobre o comércio eletrônico - o caso Amazon. Revista Direito Tributário Atual, São Paulo: Dialética, v. 26, p. 231-245, 2011.

ZIMMER, Frederik. General Report. Cahier de Droit Fiscal International, Oslo, v. 67a, p. 19-67, 2002.

ZORTÊA, Alberto João. Sociedade comercial em conta de participação. Revista Forense, Rio de Janeiro, v. 272, p. 380-387, 1980. 


\section{DECISÕES JUDICIAIS E ADMINISTRATIVAS E PRONUNCIAMENTOS ADMINISTRATIVOS}

BRASIL. Projeto de Lei n. 1572, de 2011. Brasília: Câmara dos Deputados, 2011.

Disponível em:

<http://www.camara.gov.br/proposicoesWeb/prop_mostrarintegra?codteor=888462\&filena me $=P L+1572 / 2011>$. Acesso em: 22 jul. 2018.

Projeto de Lei n. 487, de 2013. Brasília: Senado Federal. Disponível em:

$<$ https://legis.senado.leg.br/sdleg-

getter/documento?dm=4713964\&ts $=1571949092673 \&$ disposition=inline $>$. Acesso em: 26 out. 2019.

. Relatório Parcial do Livro II. Brasília: Comissão Especial da Câmara dos Deputados, destinada a proferir parecer ao Projeto de Lei n. 1572, de 2011, do Deputado Vicente Cândido, que "institui o Código Comercial". Disponível em:

<https://www.camara.leg.br/proposicoesWeb/prop_mostrarintegra;jsessionid=4F2281F963 318E5C06CA88113F5A8C09. proposicoesWebExterno1? codteor=1339923\&filename $=$ Tra mitacao-PL+1572/2011>. Acesso em: 26 out. 2019.

Relatório Parcial do Livro III. Brasília: Comissão Especial da Câmara dos Deputados, destinada a proferir parecer ao Projeto de Lei n. 1572, de 2011, do Deputado Vicente Cândido, que "institui o Código Comercial". Disponível em:

<https://www.camara.leg.br/proposicoesWeb/prop_mostrarintegra;jsessionid=4F2281F963 318E5C06CA88113F5A8C09.proposicoesWebExterno1? codteor $=1351029 \&$ filename $=$ Tra mitacao-PL+1572/2011>. Acesso em: 26 out. 2019.

Trabalhos da Comissão Especial do Código Tributário Nacional. Rio de Janeiro: IBGE, 1954.

CARF. Acórdão n. 1103-001004, de 11 mar. 2014. Brasília: CARF, $3^{\text {a }}$ Turma Ordinária, da $1^{\text {a }}$ Câmara, da $1^{\text {a }}$ Seção do CARF, 2014.

. Acórdão n. 1103-001052, de 07 maio 2014. Brasília: CARF, $3^{\text {a }}$ Turma Ordinária, da $1^{\text {a }}$ Câmara, da $1^{\text {a }}$ Seção do CARF, 2014.

. Acórdão n. 1103-001206, de 25 mar. 2015. Brasília: CARF, $3^{\text {a }}$ Turma Ordinária, da $1^{\text {a }}$ Câmara, da $1^{\text {a }}$ Seção do CARF, 2015.

. Acórdão n. 1201-001037, de 08 maio 2014. Brasília: CARF, $1^{\text {a }}$ Turma Ordinária, da $2^{\mathrm{a}}$ Câmara, da $1^{\mathrm{a}}$ Seção do CARF, 2014.

. Acórdão n. 1201-001676, de 16 maio 2017. Brasília: CARF, $1^{\text {a }}$ Turma Ordinária, da $2^{\mathrm{a}}$ Câmara, da $1^{\mathrm{a}}$ Seção do CARF, 2017.

Acórdão n. 1201-002686, de 11 dez. 2018. Brasília: CARF, $1^{\text {a }}$ Turma Ordinária, $2^{\text {a }}$ Câmara, $1^{\text {a }}$ Seção do CARF, 2018.

. Acórdão n. 1202-000649, de 22 nov. 2011. Brasília: CARF, $2^{\text {a }}$ Turma Ordinária, da $2^{\mathrm{a}}$ Câmara, da $1^{\mathrm{a}}$ Seção do CARF, 2011. 
. Acórdão n. 1202-001011, de 07 ago. 2013. Brasília: CARF, $2^{\mathrm{a}}$ Turma Ordinária, da $2^{\mathrm{a}}$ Câmara, da $1^{\mathrm{a}}$ Seção do CARF, 2013.

. Acórdão n. 1301-001789, de 04 mar. 2014. Brasília: CARF, $1^{\text {a }}$ Turma Ordinária, da $3^{\text {a }}$ Câmara, da $1^{\text {a }}$ Seção do CARF, 2014.

. Acórdão n. 1301-002593, de 17 ago. 2017. Brasília: CARF, $1^{\text {a }}$ Turma Ordinária, $3^{\text {a }}$ Câmara, $1^{\text {a }}$ Seção do CARF, 2017.

. Acórdão n. 1302-000124, de 07 dez. 2009. Brasília: CARF, $2^{\text {a }}$ Turma Ordinária, da $3^{\text {a }}$ Câmara, da $1^{\text {a }}$ Seção do CARF, 2009.

. Acórdão n. 1302-002062, de 21 mar. 2017. Brasília: CARF, $2^{\mathrm{a}}$ Turma Ordinária, da $3^{\text {a }}$ Câmara, da $1^{\text {a }}$ Seção do CARF, 2017.

. Acórdão n. 1401-001846, de 10 abr. 2017. Brasília: CARF, $1^{\text {a }}$ Turma Ordinária, $4^{\text {a }}$ Câmara, $1^{\text {a }}$ Seção do CARF, 2017.

. Acórdão n. 1401-002823, de 14 ago. 2018. Brasília: CARF, $1^{\mathrm{a}}$ Turma Ordinária, $4^{\mathrm{a}}$ Câmara, $1^{\mathrm{a}}$ Seção do CARF, 2018.

. Acórdão n. 1401-003276, de 20 mar. 2019. Brasília: CARF, $1^{\text {a }}$ Turma Ordinária, da $4^{\text {a }}$ Câmara, da $1^{\text {a }}$ Seção do CARF, 2019.

. Acórdão n. 1402-001625, de 13 mar. 2014. Brasília: CARF, $2^{\mathrm{a}}$ Turma Ordinária, da $4^{\mathrm{a}}$ Câmara, da $1^{\mathrm{a}}$ Seção do CARF, 2014.

. Acórdão n. 1402-002182, de 03 maio 2016. Brasília: CARF, $2^{a}$ Turma Ordinária, da $4^{\text {a }}$ Câmara, da $1^{\text {a }}$ Seção do CARF, 2016.

. Acórdão n. 1402-002208, de 08 jun. 2016. Brasília: CARF, $2^{a}$ Turma Ordinária, $4^{\text {a }}$ Câmara, $1^{\text {a }}$ Seção do CARF, 2016.

. Acórdão n. 1402-002685, de 26 jul. 2017. Brasília: CARF, $2^{\text {a }}$ Turma Ordinária, da $4^{\text {a }}$ Câmara, da $1^{\text {a }}$ Seção do CARF, 2017.

. Acórdão n. 2101-002318, de 15 out. 2013. Brasília: CARF, $1^{\text {a }}$ Turma Ordinária, da $1^{\text {a }}$ Câmara, da $2^{\text {a }}$ Seção do CARF, 2013.

. Acórdão n. 2102-002135, de 20 jun. 2012. Brasília: CARF, $2^{\text {a }}$ Turma Ordinária, $1^{\text {a }}$ Câmara, $2^{\text {a }}$ Seção do CARF, 2012.

. Acórdão n. 2201-002443, de 16 jul. 2014. Brasília: CARF, $1^{a}$ Turma Ordinária, da $2^{\mathrm{a}}$ Câmara, da $2^{\mathrm{a}}$ Seção do CARF, 2014.

. Acórdão n. 2202-001862, de 20 jun. 2012. Brasília: CARF, $2^{\text {a }}$ Turma Ordinária, da $2^{\mathrm{a}}$ Câmara, da $2^{\mathrm{a}}$ Seção do CARF, 2012.

. Acórdão n. 2202-003134, de 29 jan. 2016. Brasília: CARF, $2^{\text {a }}$ Turma Ordinária,

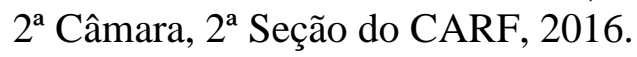


Acórdão n. 2302-003091, de 19 mar. 2014. Brasília: CARF, $2^{\text {a }}$ Turma Ordinária, $3^{\mathrm{a}}$ Câmara, $2^{\mathrm{a}}$ Seção do CARF, 2014.

Acórdão n. 2802-003065, de 13 ago. 2014. Brasília: CARF, $2^{\text {a }}$ Turma Especial, 2 Seção do CARF, 2014.

Acórdão n. 3201-004189, de 29 ago. 2018. Brasília: CARF, $1^{\text {a }}$ Turma Ordinária, $2^{\mathrm{a}}$ Câmara, $3^{\mathrm{a}}$ Seção do CARF, 2018.

CC. Acórdão n. 103-19079, de 09 dez. 1997. Brasília: CC, $3^{\text {a }}$ Câmara do $1^{\circ}$ CC, 1997.

Acórdão n. 107-06374, de 22 ago. 2001. Brasília: CC, 7ª Câmara do $1^{\circ}$ CC, 2001.

Acórdão n. 108-05636, de 17 mar. 1999. Brasília: CC, $8^{\text {a }}$ Câmara do $1^{\circ} \mathrm{CC}$,

1999.

Acórdão n. 108-06134, de 07 jun. 2000. Brasília: CC, 8 $8^{\text {a }}$ âmara do $1^{\circ}$ CC, 2000.

Acórdão n. 108-06207, de 17 ago. 2000. Brasília: CC, $8^{\text {a }}$ Câmara do $1^{\circ} \mathrm{CC}, 2000$.

Acórdão n. 108-09496, de 09 nov. 2007. Brasília: CC, 8 $8^{\text {a }}$ Câmara do $1^{\circ}$ CC, 2007.

Acórdão n. CSRF/01-0061, de 7 mar. 1980. In: CÂMARA SUPERIOR DE

RECURSOS FISCAIS. Imposto de renda - Jurisprudência 1.2-5. São Paulo: Resenha Tributária, jun. 1980. p. 1270-1278.

Acórdão n. CSRF/01-0512, de 19 abr. 1985. Revista de imposto de renda, São

Paulo: Centro de Estudos da Fiscalização do Imposto de Renda, n. 215, p. 38-45, jun. 1985.

CCRJ. Conselho de Contribuintes do Município do Rio de Janeiro. Acórdão n. 14800, de 11 dez. 2014. Rio de Janeiro: CCRJ, 2014.

CPC. Pronunciamento Técnico CPC 00. Estrutura Conceitual para Elaboração e Divulgação de Relatório Contábil-Financeiro. Brasília: CPC. Disponível em: <http://static.cpc.aatb.com.br/Documentos/147_CPC00_R1.pdf>. Acesso em: 14 fev. 2019.

Pronunciamento Técnico CPC 18. Investimento em Coligada, em Controlada e em Empreendimento Controlado em Conjunto. Brasília: CPC. Disponível em: <http://static.cpc.aatb.com.br/Documentos/263_CPC_18_(R2)_rev\%2013.pdf>. Acesso em: 17 nov. 2019.

Pronunciamento Técnico CPC 19. Negócios em conjunto. Brasília: CPC.

Disponível em:

<http://static.cpc.aatb.com.br/Documentos/274_CPC_19_\%20R2_rev\%2013.pdf>. Acesso em: 23 jan. 2019.

. Pronunciamento Técnico CPC PME. Contabilidade para pequenas e médias empresas. Brasília: CPC. Disponível em: static.cpc.aatb.com.br/Documentos/392_CPC_PMEeGlossario_R1_rev\%2014.pdf>. Acesso em: 14 dez. 2019. 
III JORNADA DE DIREITO CIVIL DO CONSELHO DA JUSTIÇA FEDERAL.

Enunciado 208. Arts. 983, 986 e 991: As normas do Código Civil para as sociedades em comum e em conta de participação são aplicáveis independentemente de a atividade dos sócios, ou do sócio ostensivo, ser ou não própria de empresário sujeito a registro (distinção feita pelo art. 982 do Código Civil entre sociedade simples e empresária). Disponível em: <https://www.cjf.jus.br/cjf/CEJ-Coedi/jornadascej/III\%20JORNADA\%20DE\%20DIREITO\%20CIVIL\%202013\%20ENUNCIADOS\%20 APROVADOS\%20DE\%20NS.\%20138\%20A\%20271.pdf/at_download/file>. Acesso em: 14 jan. 2019.

RFB. Manual de orientação do leiaute da escrituração contábil digital (ECD). Brasília: RFB. 2016. Disponível em:

<http://sped.rfb.gov.br/estatico/A8/2A167D61FEA613FD20E7E9BA101989F299E2F2/M anual_de_Orienta\%C3\%A7\%C3\%A3o_da_ECD_2016_Maio.pdf $>$. Acesso em: $14 \mathrm{fev}$. 2019.

. Solução de Consulta COSIT n. 121, de 27 maio 2014. Brasília: RFB, 2014.

Disponível em:

<http://www.receita.fazenda.gov.br/publico/Legislacao/SolucoesConsultaCosit/2014/SCCo sit1212014.pdf>. Acesso em: 02 maio 2019.

Disponível em:

. Solução de Consulta COSIT n. 139, de 3 jun. 2015. Brasília: RFB, 2015.

<http://normas.receita.fazenda.gov.br/sijut2consulta/link.action?visao=anotado\&idAto $=65$

065>. Acesso em: 22 jun. 2019.

. Solução de Consulta COSIT n. 142, 19 set. 2018. Brasília: RFB, 2018.

Disponível em:

$<$ http://normas.receita.fazenda.gov.br/sijut2consulta/link.action?idAto=95201 $>$. Acesso em: 20 nov. 2019.

Disponível em:

Solução de Consulta COSIT n. 17, de 16 jan. 2017. Brasília: RFB, 2017.

<http://normas.receita.fazenda.gov.br/sijut2consulta/link.action?visao=anotado\&idAto $=79$

749>. Acesso em: 02 maio 2019.

. Solução de Consulta COSIT n. 202, de 18 jul. 2019. Brasília: RFB, 2019.

Disponível em:

<http://normas.receita.fazenda.gov.br/sijut2consulta/link.action?visao=anotado\&idAto $=10$ 1992>. Acesso em: 09 jul. 2019.

. Solução de Consulta COSIT n. 204, de 24 jun. 2019. Brasília: RFB, 2019.

Disponível em:

$<$ http://normas.receita.fazenda.gov.br/sijut2consulta/link.action?visao=anotado\&idAto $=10$ 1909>. Acesso em: 17 nov. 2019.

. Solução de Consulta COSIT n. 28, de 23 ago. 2018. Brasília: RFB, 2018.

Disponível em:

<http://normas.receita.fazenda.gov.br/sijut2consulta/link.action?visao=anotado\&idAto=95

374>. Acesso em: 29 maio 2019. 
Solução de Consulta COSIT n. 318, de 27 dez. 2018. Brasília: RFB, 2018.

Disponível em:

<http://normas.receita.fazenda.gov.br/sijut2consulta/link.action?visao=anotado\&idAto=99 084>. Acesso em: 17 nov. 2019.

Solução de Consulta COSIT n. 56, de 29 mar. 2019. Brasília: RFB, 2019.

Disponível em:

$<$ http://normas.receita.fazenda.gov.br/sijut2consulta/link.action?visao=anotado\&idAto=99 645>. Acesso em: 29 maio 2019.

Solução de Consulta COSIT n. 59, de 27 fev. 2019. Brasília: RFB, 2019.

Disponível em:

<http://normas.receita.fazenda.gov.br/sijut2consulta/link.action?visao=anotado\&idAto=99 170>. Acesso em: 02 maio 2019.

Solução de Consulta COSIT n. 655, de 27 dez. 2017. Brasília: RFB, 2017.

Disponível em:

<http://normas.receita.fazenda.gov.br/sijut2consulta/link.action?visao=anotado\&idAto $=89$ 162>. Acesso em: 29 maio 2019.

RFB. Solução de Consulta Interna COSIT n. 12, de 15 maio 2013. Brasília: RFB, 2013. Disponível em:

<http://normas.receita.fazenda.gov.br/sijut2consulta/link.action?visao=anotado\&idAto $=50$ 784>. Acesso em: 20 jun. 2019.

Parecer Normativo COSIT n. 4, de 10.12.2018. Brasília: DOU, 12 dez. 2018, seção 1, p. 23.

SRF. Acórdão n. 05-39940, de 05 fev. 2013. Brasília: SRF, Delegacia da Receita Federal de Julgamento em Campinas, SP, $4^{\text {a }}$ Turma, 2013. Disponível em:

$<$ http://decisoes.fazenda.gov.br/netacgi/nph-brs?s7=\&s9=DRJ/\$.SIGL.\&s10=\&n=-

DTPE \&d=DECW \& $\mathrm{p}=1 \& \mathrm{u}=/$ netahtml/decisoes $/$ decw/pesquisaDRJ.htm \& $\mathrm{r}=1 \& \mathrm{f}=\mathrm{G} \& \mathrm{l}=20 \mathrm{\&}$ s1=\&s2=\&s3=05-39940\&s4=\&s5=\&s6=\&s8=>. Acesso em: 22 jun. 2019.

Acórdão n. 06-27175, de 30 jun. 2010. Brasília: SRF, Delegacia da Receita Federal de Julgamento em Curitiba, PR, $1^{\text {a }}$ Turma, 2010. Disponível em:

$<$ http://decisoes.fazenda.gov.br/netacgi/nph-brs?s7=\&s9=DRJ/\$.SIGL.\&s10=\&n=DTPE \&d=DECW \& $\mathrm{p}=1 \& \mathrm{u}=/$ netahtml/decisoes $/ \mathrm{dec}$ /pesquisaDRJ.htm $\& \mathrm{r}=1 \& \mathrm{f}=\mathrm{G} \& \mathrm{l}=20 \&$ s1=\&s3=06-27175\&s4=\&s5=\&s6=\&s8=>. Acesso em: 22 jun. 2019.

. Decisão DISIT/SRRF01 n. 51, de 05 set. 2000. Brasília: SRF, Superintendência

da Secretaria da Receita Federal da $1^{\text {a }}$ Região Fiscal, 2000. Disponível em:

$<$ http://decisoes.fazenda.gov.br/netacgi/nph-brs?s10=\&s9=NAO+DRJ/\$.SIGL.\&n=$\mathrm{DTPE} \& \mathrm{~d}=\mathrm{DECW} \& \mathrm{p}=1 \& \mathrm{u}=/$ netahtml$/ \mathrm{decisoes} / \mathrm{dec} / \mathrm{pesquisaSOL} \cdot \mathrm{htm} \& \mathrm{r}=16 \& \mathrm{f}=\mathrm{G} \& \mathrm{l}=20$ $\& s 1=\mathrm{SRRF} / 1 \% \mathrm{AA}+\mathrm{RF}+\mathrm{OU}+\mathrm{Disit}+01+\mathrm{OU}+\mathrm{Diana}+01 \& \mathrm{~s} 3=51 \& \mathrm{~s} 4=\& \mathrm{~s} 5=\& \mathrm{~s} 8=\& \mathrm{~s} 7=>$. Acesso em: 04 set. 2019.

Decisão DISIT/SRRF08 n. 13, de 11 jan. 2000. Brasília: SRF, Superintendência da Secretaria da Receita Federal da $8^{a}$ Região Fiscal, 2000. Disponível em: $<$ http://decisoes.fazenda.gov.br/netacgi/nph-brs?s10=\&s9=NAO+DRJ/\$.SIGL.\&n=$\mathrm{DTPE} \& \mathrm{~d}=\mathrm{DECW} \& \mathrm{p}=2 \& \mathrm{u}=/$ netahtml$/ \mathrm{decisoes} / \mathrm{dec}$ /pesquisaSOL.htm $\& \mathrm{r}=30 \& \mathrm{f}=\mathrm{G} \& \mathrm{l}=20$ 
$\& s 1=\mathrm{SRRF} / 8 \% \mathrm{AA}+\mathrm{RF}+\mathrm{OU}+\mathrm{Disit}+08+\mathrm{OU}+$ Diana+08\&s3=13\&s4=\&s5=\&s8=\&s7=>. Acesso em: 04 set. 2019.

Decisão DISIT/SRRF08 n. 197, de 04 set. 2000. Brasília: SRF, Superintendência da Secretaria da Receita Federal da $8^{a}$ Região Fiscal, 2000. Disponível em: $<$ http://decisoes.fazenda.gov.br/netacgi/nph-brs?s10=\&s9=NAO+DRJ/\$.SIGL.\&n=DTPE \&d=DECW \&p=2\&u=/netahtml/decisoes $/$ decw $/$ pesquisaSOL $\cdot h$ tm $\& \mathrm{r}=24 \& \mathrm{f}=\mathrm{G} \& \mathrm{l}=20$ \&s1=SRRF/8\%AA+RF+OU+Disit+08+OU+Diana+08\&s3=197\&s4=\&s5=\&s8=\&s7=>. Acesso em: 04 set. 2019.

Decisão DISIT/SRRF08 n. 199, de 5 set. 2000. Brasília: SRF, Superintendência da Secretaria da Receita Federal da $8^{a}$ Região Fiscal, 2000. Disponível em: $<$ http://normas.receita.fazenda.gov.br/sijut2consulta/link.action?visao=anotado\&idAto $=63$ 463>. Acesso em: 22 jun. 2019.

Decisão DISIT/SRRF09 n. 03, de 01 jan. 2001. Brasília: SRF, Superintendência da Secretaria da Receita Federal da $9^{a}$ Região Fiscal, 2001. Disponível em: $<$ http://decisoes.fazenda.gov.br/netacgi/nph-brs?s10=\&s9=NAO+DRJ/\$.SIGL.\&n=DTPE \&d=DECW \&p=2\&u=/netahtml/decisoes/decw/pesquisaSOL.htm\&r=22\&f=G\&l=20 $\& s 1=\& s 3=\& s 4=\& s 5=s c p+e+l u c r o \& s 8=\& s 7=>$. Acesso em: 04 set. 2019.

Decisão DISIT/SRRF10 n. 89, de 05 jun. 2001. Brasília: SRF, Superintendência

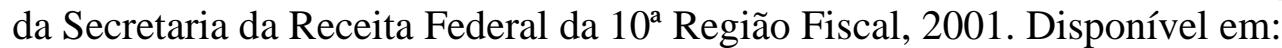
$<$ http://decisoes.fazenda.gov.br/netacgi/nph-brs?s10=\&s9=NAO+DRJ/\$.SIGL.\&n=DTPE \&d=DECW \&p=2\&u=/netahtml/decisoes/decw/pesquisaSOL.htm\&r=21\&f=G\&l=20 $\&$ s1=\&s3=\&s4=\&s5=scp+e+lucro\&s8=\&s7=>. Acesso em: 04 set. 2019.

. Solução de Consulta DISIT/SRRF03 n. 8, de 27 fev. 2012. Brasília: SRF, Superintendência da Secretaria da Receita Federal da $3^{\text {a }}$ Região Fiscal, 2012. Disponível em:

$<$ http://normas.receita.fazenda.gov.br/sijut2consulta/link.action?visao=anotado\&idAto $=59$ 388>. Acesso em: 22 jun. 2019.

Solução de Consulta DISIT/SRRF04 n. 63, de 31 ago. 2006. Brasília: SRF, Superintendência da Secretaria da Receita Federal da $4^{\mathrm{a}}$ Região Fiscal, 2006. Disponível em: <http://decisoes.fazenda.gov.br/netacgi/nph-brs?s10=\&s9=NAO+DRJ/\$.SIGL.\&n=$\mathrm{DTPE} \& \mathrm{~d}=\mathrm{DECW} \& \mathrm{p}=1 \& \mathrm{u}=/$ netahtml/decisoes/decw/pesquisaSOL.htm $\& \mathrm{r}=12 \& \mathrm{f}=\mathrm{G} \& \mathrm{l}=20$ $\& s 1=\mathrm{SRRF} / 4 \% \mathrm{AA}+\mathrm{RF}+\mathrm{OU}+\mathrm{Disit}+04+\mathrm{OU}+\mathrm{Diana}+04 \& \mathrm{~s} 6=\mathrm{SC}+\mathrm{OU}+\mathrm{DE} \& \mathrm{~s} 3=63 \& \mathrm{~s} 4=\& \mathrm{~s} 5$ $=\& s 8=\& s 7=>$. Acesso em: 09 jul. 2019.

. Solução de Consulta DISIT/SRRF06 n. 46, de 24 maio 2010. Brasília: SRF, Superintendência da Secretaria da Receita Federal da $6{ }^{\text {a }}$ Região Fiscal, 2010. Disponível em:

$<$ http://normas.receita.fazenda.gov.br/sijut2consulta/link.action?visao=anotado\&idAto $=65$ 310>. Acesso em: 29 maio 2019.

. Solução de Consulta DISIT/SRRF08 n. 11, de 15 jan. 2009. Brasília: SRF, Superintendência da Secretaria da Receita Federal da $8^{\text {a }}$ Região Fiscal, 2009. Disponível em:

$<$ http://normas.receita.fazenda.gov.br/sijut2consulta/link.action?visao=anotado\&idAto $=71$ 673>. Acesso em: 08 jul. 2019. 
Solução de Consulta DISIT/SRRF08 n. 47, de 19 fev. 2009. Brasília: SRF, Superintendência da Secretaria da Receita Federal da $8^{a}$ Região Fiscal, 2009. Disponível em: <http://decisoes.fazenda.gov.br/netacgi/nph-brs?s10=\&s9=NAO+DRJ/\$.SIGL.\&n=$\mathrm{DTPE} \& \mathrm{~d}=\mathrm{DECW} \& \mathrm{p}=1 \& \mathrm{u}=/$ netahtml$/ \mathrm{decisoes} / \mathrm{dec} / \mathrm{pesquisaSOL} \cdot \mathrm{htm} \& \mathrm{r}=13 \& \mathrm{f}=\mathrm{G} \& \mathrm{l}=20$ $\& \mathrm{~s} 1=\mathrm{SRRF} / 8 \% \mathrm{AA}+\mathrm{RF}+\mathrm{OU}+\mathrm{Disit}+08+\mathrm{OU}+\mathrm{Diana}+08 \& \mathrm{~s} 6=\mathrm{SC}+\mathrm{OU}+\mathrm{DE} \& \mathrm{~s} 3=47 \& \mathrm{~s} 4=\& \mathrm{~s} 5$ $=\& s 8=\& s 7=>$. Acesso em: 09 jul. 2019.

. Solução de Consulta DISIT/SRRF08 n. 8 , de 09 fev. 2012. Brasília: SRF, Superintendência da Secretaria da Receita Federal da $8^{\text {a }}$ Região Fiscal, 2012. Disponível em:

<http://normas.receita.fazenda.gov.br/sijut2consulta/link.action?visao=anotado\&idAto $=84$ 655>. Acesso em: 22 jun. 2019.

Solução de Consulta DISIT/SRRF09 n. 80, de 16 abr. 2012. Brasília: SRF, Superintendência da Secretaria da Receita Federal da 9 $9^{a}$ Região Fiscal, 2012. Disponível em: <http://decisoes.fazenda.gov.br/netacgi/nph-brs?s10=\&s9=NAO+DRJ/\$.SIGL.\&n=DTPE \&d=DECW \&p=1\&u=/netahtml/decisoes/decw/pesquisaSOL.htm $\& \mathrm{r}=2 \& \mathrm{f}=\mathrm{G} \& \mathrm{l}=20$ $\& \mathrm{~s} 1=\mathrm{SRRF} / 9 \% \mathrm{AA}+\mathrm{RF}+\mathrm{OU}+\mathrm{Disit}+09+\mathrm{OU}+\mathrm{Diana}+09 \& \mathrm{~s} 6=\mathrm{SC}+\mathrm{OU}+\mathrm{DE} \& \mathrm{~s} 3=80 \& \mathrm{~s} 4=\& \mathrm{~s} 5$ $=\& s 8=\& s 7=>$. Acesso em: 09 jul. 2019.

Solução de Consulta DISIT/SRRF10 n. 89, de 05 jun. 2001. Brasília: SRF, Superintendência da Secretaria da Receita Federal da $10^{\text {a }}$ Região Fiscal, 2001. Disponível em: <http://decisoes.fazenda.gov.br/netacgi/nph-brs?s10=\&s9=NAO+DRJ/\$.SIGL.\&n=$\mathrm{DTPE} \& \mathrm{~d}=\mathrm{DECW} \& \mathrm{p}=2 \& \mathrm{u}=/$ netahtml $/$ decisoes $/ \mathrm{dec} / \mathrm{pesquisaSOL} \cdot \mathrm{htm} \& \mathrm{r}=23 \& \mathrm{f}=\mathrm{G} \& \mathrm{l}=20$ $\& \mathrm{~s} 1=\mathrm{SRRF} / 10 \% \mathrm{AA}+\mathrm{RF}+\mathrm{OU}+\mathrm{Disit}+10+\mathrm{OU}+\mathrm{Diana}+10 \& \mathrm{~s} 6=\mathrm{SC}+\mathrm{OU}+\mathrm{DE} \& \mathrm{~s} 3=89 \& \mathrm{~s} 4=\& \mathrm{~s}$ 5=\&s8=\&s7=>. Acesso em: 09 jul. 2019.

STJ. Recurso Especial n. 1200492-RS. $1^{\text {a }}$ Seção, Relator Ministro Napoleão Nunes Maia Filho, Relator para acórdão Ministro Mauro Campbell Marques, Brasília, j. 14 out. 2015.

Recurso Especial n. 1230981-RJ. $3^{\text {a }}$ Turma, Relator Ministro Marco Aurélio Bellizze, Brasília, j. 16 dez. 2014.

Recurso Especial n. 1373438-RS. $2^{\text {a }}$ Seção, Relator Ministro Paulo de Tarso Sanseverino, Brasília, j. 11 jun. 2014.

Recurso Especial n. 168028-SP. $4^{\text {a }}$ Turma, Relator Ministro Cesar Asfor Rocha, Brasília, j. 07 ago. 2001.

. Recurso Especial n. 193690-PR. $2^{\text {a }}$ Turma, Relator Ministro Franciulli Netto, Brasília, j. 04 jun. 2002.

Recurso Especial n. 474704-PR. $3^{\text {a }}$ Turma, Relator Ministro Carlos Alberto Menezes Direito, Brasília, j. 17 dez. 2002. 05 fev. 2009.

Recurso Especial n. 884845-SC. $1^{\text {a }}$ Turma, Relator Ministro Luiz Fux, Brasília, j.

. Recurso Extraordinário n. 651703-PR. Tribunal Pleno, Relator Ministro Luiz Fux, Brasília, j. 29 set. 2016. 
TRF1. Mandado de Segurança n. 1001501-64.2015.4.01.3400. $2^{\mathrm{a}}$ Vara da Seção Judiciária do Distrito Federal, Juiz Federal Charles Renaud Frazão de Moraes, Brasília, j. 06 abr. 2015. 